\title{
Cheese Whey Processing: Integrated Biorefinery Concepts and Emerging Food Applications
}

\author{
Iliada K. Lappa ${ }^{1,+}\left(\mathbb{D}\right.$, Aikaterini Papadaki ${ }^{1,+}+\mathbb{D}$, Vasiliki Kachrimanidou $1,2, * \mathbb{0}$, \\ Antonia Terpou ${ }^{1}\left(\mathbb{D}\right.$, Dionysios Koulougliotis ${ }^{3}$, Effimia Eriotou ${ }^{1}$ and Nikolaos Kopsahelis ${ }^{1, * \mathbb{D}}$ \\ 1 Department of Food Science and Technology, Ionian University, Argostoli, 28100 Kefalonia, Greece \\ 2 Department of Food and Nutritional Sciences, University of Reading, Berkshire RG6 6AP, UK \\ 3 Department of Environment, Ionian University, Panagoula, 29100 Zakynthos, Greece \\ * Correspondence: v.kachrimanidou@reading.ac.uk (V.K.); kopsahelis@upatras.gr (N.K.) \\ + Equal contribution as first author.
}

Received: 22 July 2019; Accepted: 10 August 2019; Published: 15 August 2019

\begin{abstract}
Cheese whey constitutes one of the most polluting by-products of the food industry, due to its high organic load. Thus, in order to mitigate the environmental concerns, a large number of valorization approaches have been reported; mainly targeting the recovery of whey proteins and whey lactose from cheese whey for further exploitation as renewable resources. Most studies are predominantly focused on the separate implementation, either of whey protein or lactose, to configure processes that will formulate value-added products. Likewise, approaches for cheese whey valorization, so far, do not exploit the full potential of cheese whey, particularly with respect to food applications. Nonetheless, within the concept of integrated biorefinery design and the transition to circular economy, it is imperative to develop consolidated bioprocesses that will foster a holistic exploitation of cheese whey. Therefore, the aim of this article is to elaborate on the recent advances regarding the conversion of whey to high value-added products, focusing on food applications. Moreover, novel integrated biorefining concepts are proposed, to inaugurate the complete exploitation of cheese whey to formulate novel products with diversified end applications. Within the context of circular economy, it is envisaged that high value-added products will be reintroduced in the food supply chain, thereby enhancing sustainability and creating "zero waste" processes.
\end{abstract}

Keywords: food processing; integrated biorefineries; circular-economy; whey proteins; lactose esters; prebiotics; hydrogels; edible films; bacterial cellulose; carotenoids

\section{Introduction}

Design of integrated biorefinery concepts endeavors a consolidated approach to valorize all possible waste and by-product streams under the concept of circular economy. In line with this, it is a prerequisite to target the formulation of multitude products rather than a single product to secure sustainable processes. On top of that, the high-value products will need to find value-added end applications, whereas the food sector is deemed of high importance. Food products with added value will ultimately meet consumers' demands and confer possible health benefits.

Cheese whey constitutes a by-product of the dairy industry and refers to the liquid stream deriving from the transformation of milk into cheese, specifically from the process of agglomeration of casein micelles. Whey is mainly composed of water, but also contains around $50 \%$ of the milk solids $[1,2]$. The dry matter fraction retains most of the lactose $(66-77 \%, w / w), 8-15 \%(w / w)$ of numerous types of globular proteins, along with $7-15 \%(w / w)$ of minerals salts [3]. The amount of whey generated relates to the amount of cheese production and also to the productivity based on the type of milk, whereby approximately $9 \mathrm{~L}$ of whey are obtained for every $1 \mathrm{~kg}$ of cheese produced [4,5]. 
Over the last decades, cheese whey is considered the most important pollutant of the dairy industry, associated with serious environmental hazards in the case that designated sustainable treatments are not applied. The major issue lies in the high organic load, mainly due to the high content of lactose but also to the occurrence of hardly-biodegradable proteins [6]. More specifically, chemical oxygen demand (COD) of cheese whey can vary from 50,000 to $80,000 \mathrm{mg} / \mathrm{L}$, whereas biochemical oxygen demand (BOD) is around 40,000 to $60,000 \mathrm{mg} / \mathrm{L}$ [7]. The rapid consumption of oxygen in the soil caused from the breakdown of proteins and sugars present in whey poses a significant disposal problem, in line with the vast amounts of volumes generated. The global whey production in 2016 was estimated at 200 million $t$ with an annual linear increase of $3 \%$ for the last 21 years [8].

Nonetheless, in the last decades, cheese whey characterization has been altered from waste to dairy side-stream product. Significant research has been conducted to mitigate viable and environmentally benign valorization alternatives for cheese whey, rather than just field disposal $[9,10]$. The high nutritional value of cheese whey [11,12] has induced the valorization of approximately $50 \%$ of residual whey [13-15] towards the generation of value-added products for food and chemical industries. Traditional uses of whey protein as a health promoter have been earlier reported, both in human and animal nutrition [16]. Furthermore, several process technologies and biotechnological approaches have also been developed to convert this by-product into a resource of valuable components or into an ample range of marketable beverages [17-19]. Scientific studies have demonstrated the nutritional and functional value of whey protein and have focused on developing a number of recovery methods via physicochemical processes [20-22]. Advanced technologies such as ultrafiltration and nanofiltration have enhanced the exploitation of whey streams $[5,23,24]$. Besides the implementation of these techniques, the deproteinized cheese whey constitutes a lactose-rich fraction, and still displays a $\mathrm{BOD}_{5}$ $>30 \mathrm{~kg} \mathrm{~m}^{-3}$ [25]. Equally, the obtained fraction exhibits a high organic pollutant that should be further treated or employed as onset material for valorization processes.

Microbial-based processes to convert cheese whey into valuable products have flourished as a potential route for biorefinery development. Fermentation processes could significantly decrease the organic load (lactose content), thus enabling an economical and feasible alternative utilization of cheese whey, thereby reducing the environmental impact. However, to the best of our knowledge, there are scarce studies performed to evaluate both whey fractions in the frame of an integrated and consolidated approach which could find applications within the food industry itself. Bioprocess integration is defined as the simultaneous incorporation of more than two-unit operations in a single process, thereby enabling the utilization of an organic-rich effluent like cheese whey to generate multiple additional products.

The purpose of this study is to elaborate an overview on the conversion of whey deriving from cheese manufacture to high value-added products. Recent developments and new insights in the processing and refining technologies for cheese whey exploitation are reported, while advanced approaches with special focus on food applications are taken into consideration. The overall aim of this article is to explore potential schemes that could be applied for this by-product, by introducing the concept of novel biorefineries. Novel and cost-effective exploitation concepts have emerged to be of paramount importance, thus potential research gaps are also identified by proposing holistic approaches of cheese whey valorization to formulate a multitude of end-products. Therefore, biorefining processes that implement the valorization of lactose and whey protein towards the formulation of high value-added products through enzymatic, microbial, and chemical methods are proposed. Ultimately, it is anticipated that novel and functional foods with enhanced properties will be the target end-products, allowing the reintroduction in the food manufacturing sector, within the concept of transitioning to a closed-loop circular economy.

\section{Bioprocess Development Using Whey Lactose}

The deployment of cascade bioprocesses, to foster a holistic approach for cheese whey valorization and mitigate its disposal, has gained significant scientific attention during the last years. Pharmaceutical 
and food industries exhibit potential market outlets for the lactose fraction deriving from cheese whey. Special attention is given in the production of added-value compounds as a result of enzymatic catalysis or microbial fermentations. In this context, the production of lactic acid, ethanol, microbial lipids, microbial biomass, single cell protein, poly-hydroxyalkanoates, enzymes, and endo-polysaccharides has been addressed in numerous studies dealing with the exploitation of whey lactose [13,26,27]. However, this article will focus on novel, promising, and not fully developed or extensively studied bioprocesses from whey lactose, targeting food applications in the context of functional food manufacture. In particular, the synthesis of lactose derivatives, mainly as novel and targeted prebiotic oligosaccharides and fatty acids esters, has lately attracted great interest [28-30]. Likewise, various food additives and functional components, such as biocolorants, medicinal mushrooms, spirulina, etc., can be produced through microbial fermentations. These aspects and other recent trends in the field of whey lactose upgrading are described in the following sections.

\subsection{Enzymatic Bioprocesses}

\subsubsection{Galacto-Oligosaccharides}

The prebiotic definition has been constantly evolving since the first definition in 1995 by Gibson and Roberfroid [31], being recently revised as "a substrate that is selectively utilized by host microorganisms conferring a health benefit" [32]. Prebiotic oligosaccharides are non-digestible compounds, varying in the composition and configuration of monosaccharide residues and the type of glycosidic linkages. Prebiotics confer beneficial effects on human health, primarily by modifying the indigenous colonic gut microbiota [33]. Prebiotic oligosaccharides can be found in fruit, vegetable, dairy, and seafood processing by-products, while they can also be enzymatically synthesized [34]. Galacto-oligosaccharides (GOS) and lactulose are well established and recognized prebiotics, based on their health-promoting effects, including immunomodulation, lipid metabolism, mineral absorption, weight management, and obesity-related issues, among others [35].

Galacto-oligosaccharides are non-digestible, galactose-containing oligosaccharides with a unit of terminal glucose in the form Glu $\alpha 1-4(\beta$ Gal 1-6)n, showing a degree of polymerization (DP) ranging from 2 to $8-9[36,37]$. GOS are produced by lactose, through the transgalactosylation action of $\beta$-galactosidase (EC 3.2.1.23), yielding a mixture of oligosaccharides, mono- and disaccharides, with a high range of linkages, mainly $\beta 1-4$ and $\beta 1-6$, but also $\beta 1-3$ and $\beta 1-2$ [38]. GOS occur naturally in the milk of animals and humans at low concentrations, but they are mainly produced by chemical glycosylation or enzymatic routes to meet market demands. The worldwide market size of GOS was estimated at $\$ 703.8$ million in 2017 , and it is anticipated to increase significantly by 2025 , following the constantly-rising demand for the consumption of dietary supplements [39]. The prebiotic effect of GOS has been widely demonstrated during in vitro animal and human studies (including studies with infants). GOS have been recognized as safe (GRAS) in the United States and are characterized as foods for specific health use (FOSHU) in Japan, where they have been applied in a spectrum of end-products such as sweeteners, bulking agents, and sugar substitutes [38,40,41]. Thereby, GOS are mostly applied to infant formula products, aiming to formulate products similar to human milk composition, but also in beverages, meal replacers, flavored milk, and confectionery products (e.g., bread). Their incorporation into food products has been regulated in many countries, which are using GOS as functional food ingredients, whereas in Europe, they are under pre-screening evaluation from the European Food Safety Authority (EFSA) [41,42]. Apart from the food industry, GOS have found applications in the animal feed, cosmetic, and pharmaceutical industries.

Another lactose-derived prebiotic is lactulose (4-O- $\beta$-D-galactopyranosyl-D-fructose), a non-digestible synthetic disaccharide, comprising of fructose and galactose [30]. Lactulose has been marketed mainly as a medical product [37], finding many applications in food products such as milk for bottle-fed babies to adjust the composition of their colonic microbiota [43]. 
The chemical route is a common method for the production of GOS and lactulose. The main drawbacks of the chemical synthesis are the requirement of catalysts and chemicals, the low specificity, and the production of undesirable compounds. However, many companies have employed enzymatic synthesis, as it offers several advantages, including the requirement of non-purified substrates, selectivity, mild reaction conditions, and lower downstream operation costs [30]. The enzymatic production and the final configuration of GOS, in terms of molecular weight distribution and linkages, are affected by various factors, including the concentration of lactose and water during the reaction and the source of the enzyme employed. The biocatalyst $\beta$-galactosidase can be obtained from several microbial sources, including Kluyveromyces lactis, Bacillus circulans, Bifidobacterium bifidum, Aspergillus oryzae, and Streptococcus thermophiles [44]. During GOS synthesis with $\beta$-galactosidases, lactose acts both as donor and acceptor of the transgalactosylated galactose [45], whereas during lactulose synthesis, lactose is the galactosyl donor and fructose acts as the acceptor. However, a mixture of lactulose and GOS is produced during lactulose synthesis, as lactose and fructose are simultaneously present in the reaction medium and, thus, can act as acceptors and their production ratio depends on the process conditions [46]. Likewise, GOS purification steps are essential when food applications are targeted. Hernández et al. [36] evaluated several fractionation techniques, showing the potential of yeast treatment to obtain high purity GOS, compared to diafiltration and activated charcoal [36].

The use of whey lactose has been suggested as an alternative substrate for the enzymatic synthesis of potential prebiotics, leading to a more sustainable and competitive process within the concept of bioeconomy. Although there are many studies reporting GOS production using primarily pure lactose [28], research has been also conducted using whey lactose as substrate. Lactose from whey can be obtained via crystallization of a supersaturated solution [41]. Wichienchot and Ishak [47] suggested that lactose derived from cheese whey is a potential source for GOS and lactulose production [47]. Splechtna et al. [48] found that GOS production, catalyzed by a $\beta$-galactosidase of Lactobacillus sp., was reduced compared to buffered lactose substrate, whereby GOS yield was $28 \%$ of total sugars. However, higher yields have been reported by other studies [48]. Das et al. [49] reported 77\% GOS production from whey lactose by employing $\beta$-galactosidase from Bacillus circulans [49]. High GOS production $(53.45 \mathrm{~g} / \mathrm{L})$ has been also produced from lactose-supplemented whey, catalyzed by the $\beta$-galactosidase of Streptococcus thermophilus [35]. Díez-Municio et al. [50] indicated that cheese whey is a suitable material for the synthesis of the trisaccharide 2- $\alpha$-D-glucopyranosyl-lactose [50]. The authors mentioned a yield of $50 \%$ of the initial amount of lactose, under the optimum reaction conditions. A co-reaction was performed using bovine cheese whey and tofu whey as lactose and sucrose sources, respectively, for the production of $80.1 \mathrm{~g} / \mathrm{L}$ lactosucrose. This approach allowed the simultaneous utilization of two by-products which resulted in a very high productivity of $40.1 \mathrm{~g}$ lactosucrose $/ \mathrm{L} / \mathrm{h}$ [51]. In another study, a continuous reaction was performed using $\beta$-glucosidase from Kluyveromyces lactis, achieving a maximum yield of $31 \%$ oligosaccharides in a pilot plant scale UF-hollow fiber membrane reactor [52]. Lower yields up to $11.3 \%$ of GOS have been obtained in other studies using different types of cheese whey (sweet whey, acid whey) [53]. Overexpression of $\beta$-galactosidase from S. thermophilus in a food grade L. plantarum strain resulted in the production of $50 \%$ of GOS using $205 \mathrm{~g} / \mathrm{L}$ of lactose derived from whey [54], thus indicating an efficient valorization route for whey lactose.

For the commercial production of GOS, Nestle company has developed a procedure using partially demineralized sweet whey permeate. Initially, whey is concentrated and then $\beta$-glucosidase produced from A. oryzae is added and the reaction is stopped through heat inactivation of the enzyme [42].

Scott et al. [55] performed a techno-economic analysis to evaluate the production of whey powder and lactose as market outlet for subsequent GOS production [55]. The plant capacity, along with the current prices of whey powder and lactose, were closely affected with the profitability of the complete process. Nonetheless, the authors suggested that the bioprocess and restructuring of the plant could become more robust if the price of whey powder rises [55]. On the other hand, the development of integrated cheese whey biorefineries towards the production of added-value products, from both lactose and whey protein streams, could exploit the full potential of cheese whey, including process 
optimization and downstream recovery that could be annexed to other bioprocesses. Added-value products from whey protein, and the possibility to configure cascade bioprocessing for cheese whey, will be elaborated in the following sections, proposing the development of robust integrated scenarios.

\subsubsection{Lactose Fatty Acid Esters}

Sugar esters are odorless, non-toxic, and biodegradable compounds of high importance for the food industry [30]. The most common sugar esters derive from sucrose, with an estimated global market of $\$ 74.6$ million in 2020 [56]. Although, lactose esters have not been extensively studied, they have found several applications within the food, cosmetic, and pharmaceutical industries [57]. These sugar esters demonstrate excellent emulsifying and stability properties in food products, whereas they may be applied as low-fat alternatives. Additionally, they present antimicrobial activity against many foodborne pathogens, as well as medicinal properties such as anticancer activity [30,57].

Chemical synthesis of lactose esters is the most common route for their production. The main drawback of the chemical lactose esterification is the production of non-stereospecific esters [57]. The use of enzymes, such as lipases, esterases, and proteases, affects the reaction selectivity due to their regiospecifity [57]. Among all enzymes, lipases have attracted significant interest due to their stability during several batch reactions at high temperatures and their ability to utilize different substrates [57-61].

Lactose ester production has been studied since 1974 [62]. An extensive review for lactose ester production through enzymatic catalysis demonstrated that enzymes from various microbial sources-e.g., Candida antarctica, Mucor miehei, and Pseudomonas cepasia, among others-can be utilized, entailing high yields. More specifically, lipases have achieved yields up to $89 \%$, whereas the protease from Bacillus subtilis reached the highest yield $(96 \%)$, at mild temperature conditions $\left(45^{\circ} \mathrm{C}\right)[63,64]$. During sugar ester synthesis, fatty acid vinyl esters are utilized as acyl donors. Since vinyl esters are expensive and result in unstable by-products (vinyl alcohols), Enayati et al. [65] replaced them with fatty acids, such as lauric acid and palmitic acid, which yielded high lactose ester synthesis (93\%) [65]. This method could be further developed by employing renewable resources with a high content of free fatty acids, such as fatty acid distillates. For instance, palm fatty acid distillate has been successfully valorized towards polyol ester production using a commercial lipase [61]. Even though lactose esters have been recognized for their superior properties and as attractive substitutes of synthetic surfactants [65,66], only pure lactose has been employed for their production until now [57].

\subsection{Microbial Bioprocesses}

\subsubsection{Food Biocolorants and Aroma Compounds}

Carotenoids are considered one of the most important groups of natural pigments, exhibiting numerous biological functions. Carotenoids are characterized by their antioxidant activity and their exceptional health benefits on human health, such as the reduction of cardiovascular diseases, anti-diabetic, anti-cancer, and anti-inflammation activities [67-69]. Humans are not able to synthesize carotenoids; thus, their uptake can be only performed via the consumption of carotenoid-rich food products. The most commercially important carotenoid is $\beta$-carotene, followed by lutein and astaxanthin. Likewise, $\beta$-carotene is widely applied as a food supplement, acting as provitamin $\mathrm{A}$, and as a coloring agent in food products, such as butter, margarine, cheese, confectionery, ice cream, juices, other beverages, etc. [70,71]. Natural astaxanthin has gained industrial interest as it presents significantly higher antioxidant activity than the respective counterpart made via the chemical route [72]. Astaxanthin is widely utilized in salmon aquaculture and as a dietary-supplement for human consumption [71,73].

Carotenoids were initially extracted from plants, but they are currently produced primarily through chemical synthesis. Natural origin carotenoids can be obtained only through plant extraction or biotechnologically. The fermentative production of carotenoids has been well-investigated using 
various carbon sources, such as glucose, sucrose, and xylose, among others; however, the interest has been shifted to the use of low-cost substrates, aiming to reduce the high production cost. In this context, there is a growing interest for the development of bioprocesses using renewable resources as alternative carbon sources [71]. The fungus Blakeslea trispora, as well as many yeast species belonging to the genera of Rhodosporidium sp. Rhodotorula sp. and Phaffia rhodozyma, have been studied for carotenoid production using low-cost substrates [71,74]. Usually, most of them produce a mixture of carotenoids consisting of $\beta$-carotene, torulene, torularodine, and $\gamma$-carotene [71]. In the case of $P$. rhodozyma, the carotenoid mixture primarily comprises astaxanthin [75]. The microalgae Haematococcus pluvialis also constitutes a rich source of astaxanthin, thus presents the highest potential for astaxanthin production [73].

Among renewable resources, cheese whey has emerged as a promising candidate for carotenoid production, however only a few studies are found in the literature. Cheese whey, or deproteinized cheese whey, has been utilized for the production of carotenoids using various microorganisms. Nevertheless, most of them are lactose-negative species, thus in many cases, enzymatic hydrolysis of deproteinized cheese whey is carried out prior to fermentation. Table 1 summarizes all the results with respect to carotenoid production from cheese whey up-to-date. Evidently, B. trispora demonstrates the highest yields among all microorganisms. The highest carotene production of $1620 \mathrm{mg} / \mathrm{L}$ with an intracellular yield of $222 \mathrm{mg} / \mathrm{g}$ was reported by Roukas et al. [76]. The fermentation was carried out in a bubble column reactor using deproteinized, hydrolyzed cheese whey. This is among the highest values achieved with agro-industrial by-products, indicating that cheese whey might be one of the most promising renewable resources for the commercial production of carotenes. Table 1 also shows that the selection of the proper microbial strains can lead to the production of specific carotenoid types. For instance, carotenoids rich in canthaxanthin can be obtained by the bacterium Dietzia natronolimnaea [77]. Apparently, astaxanthin production has not been studied yet implementing cheese whey as substrate. This can be attributed to the fact that P. rhodozyma cannot assimilate lactose and galactose [78], whereas among several sugars, lactose results in the lowest astaxanthin production using the microalgae Chlorella zofingiensis [79].

Carotenoid production — and particularly the proportions of individual carotenoids-correlate to several factors (e.g., the addition of surfactants and vegetable oils) along with culture conditions, (e.g., aeration rate) [76,80-82]. Interestingly, these studies have suggested the potential combination of oil by-products with cheese whey to foster a promising and circular valorization of food by-products for carotenoid generation.

Table 1. Carotenoid production from various microorganisms through fermentation in cheese whey $(\mathrm{CW})$.

\begin{tabular}{|c|c|c|c|c|c|}
\hline Microorganism & $\begin{array}{l}\text { Supplementation } \\
\text { of CW Medium }\end{array}$ & $\begin{array}{l}\text { Composition of } \\
\text { Total Carotenoids }\end{array}$ & $\begin{array}{c}\text { Concentration } \\
(\mathrm{mg} / \mathrm{L})\end{array}$ & $\begin{array}{c}\text { Yield } \\
(\mathrm{mg} / \mathrm{g})^{1}\end{array}$ & Reference \\
\hline $\begin{array}{l}\text { Blakeslea trispora } \\
\text { ATCC } 14271 \& \\
\text { ATCC } 14272\end{array}$ & $\begin{array}{l}\text { Tween } 80, \text { Span } \\
80, \beta \text {-ionone }\end{array}$ & $\begin{array}{l}\beta \text {-carotene, } \\
\gamma \text {-carotene, } \\
\text { lycopene }\end{array}$ & 1620.0 & 222.0 & [76] \\
\hline $\begin{array}{l}\text { Blakeslea trispora } \\
\text { ATCC } 14271 \& \\
\text { ATCC } 14272\end{array}$ & $\begin{array}{c}\text { Tween } 80, \text { Span } \\
80, \beta \text {-ionone }\end{array}$ & $\begin{array}{l}\beta \text {-carotene, } \\
\gamma \text {-carotene, } \\
\text { lycopene }\end{array}$ & 1360.0 & 175.0 & [83] \\
\hline $\begin{array}{c}\text { Blakeslea trispora } \\
\text { ATCC } 14271 \& \\
\text { ATCC } 14272\end{array}$ & $\begin{array}{l}\text { Tween } 80, \text { Span } \\
\text { 80, vegetable oils }\end{array}$ & $\begin{array}{l}\beta \text {-carotene, } \\
\gamma \text {-carotene, } \\
\text { lycopene }\end{array}$ & $\sim 672.0$ & 16.0 & [82] \\
\hline $\begin{array}{c}\text { Blakeslea trispora } \\
\text { ATCC } 14271 \& \\
\text { ATCC } 14272\end{array}$ & $\begin{array}{l}\text { Tween } 80, \text { Span } \\
\text { 80, vegetable oils, } \\
\text { antioxidants and } \\
\text { other nutrients }\end{array}$ & $\beta$-carotene & 350.0 & 11.6 & [84] \\
\hline
\end{tabular}


Table 1. Cont.

\begin{tabular}{|c|c|c|c|c|c|}
\hline Microorganism & $\begin{array}{l}\text { Supplementation } \\
\text { of CW Medium }\end{array}$ & $\begin{array}{c}\text { Composition of } \\
\text { Total Carotenoids }\end{array}$ & $\begin{array}{c}\text { Concentration } \\
(\mathrm{mg} / \mathrm{L})\end{array}$ & $\begin{array}{c}\text { Yield } \\
(\mathrm{mg} / \mathrm{g})^{1}\end{array}$ & Reference \\
\hline $\begin{array}{l}\text { Blakeslea trispora } \\
\text { ATCC } 14271 \\
\text { \&ATCC } 14272\end{array}$ & $\begin{array}{l}\text { Tween } 80 \text {, Span } \\
80 \text {, vegetable oils }\end{array}$ & N.S. ${ }^{2}$ & 376.0 & 8.0 & [85] \\
\hline $\begin{array}{c}\text { Mucor azygosporus } \\
\text { MTCC } 414\end{array}$ & Soluble starch & $\beta$-carotene & 3.5 & 0.38 & [86] \\
\hline $\begin{array}{c}\text { Rhodotorula } \\
\text { mucilaginosa NRRL } \\
2502\end{array}$ & & N.S. ${ }^{2}$ & 70.0 & 29.2 & [80] \\
\hline $\begin{array}{c}\text { Rhodotorula } \\
\text { mucilaginosa CCY } \\
20-7-31\end{array}$ & & $\beta$-carotene & 11.3 & 0.38 & [87] \\
\hline $\begin{array}{l}\text { Rhodotorula glutinis } \\
\text { CCY } 20-2-26\end{array}$ & & $\beta$-carotene & 51.2 & 1.48 & [87] \\
\hline $\begin{array}{c}\text { Rhodotorula rubra } \\
\text { GED5 co-culture } \\
\text { with Kluyveromyces } \\
\text { lactis MP11 }\end{array}$ & & $\begin{array}{l}\text { Torularhodin, } \\
\beta \text {-carotene, } \\
\text { torulene }\end{array}$ & 10.2 & 0.42 & [88] \\
\hline $\begin{array}{l}\text { Rhodotorula glutinis } \\
\text { 22P co-culture with } \\
\text { Lactobacillus } \\
\text { helveticus }\end{array}$ & & $\begin{array}{l}\beta \text {-carotene, } \\
\text { torularhodin, } \\
\text { torulene }\end{array}$ & 8.09 & 0.27 & [89] \\
\hline $\begin{array}{c}\text { Rhodotorula rubra } \\
\text { GED8 co-culture } \\
\text { with Lactobacillus } \\
\text { bulbaricus, } \\
\text { Streptococcus } \\
\text { thermophilus }\end{array}$ & & $\begin{array}{c}\beta \text {-carotene, } \\
\text { torulene, } \\
\text { torularhodin }\end{array}$ & 13.1 & 0.50 & [90] \\
\hline $\begin{array}{c}\text { Sporidiobolus } \\
\text { salmonicor CBS } \\
2636\end{array}$ & & N.S. ${ }^{2}$ & 0.91 & 0.25 & [91] \\
\hline $\begin{array}{c}\text { Sporobolomyces } \\
\text { roseus CCY 19-4-8 }\end{array}$ & & $\beta$-carotene & 29.4 & 2.89 & [87] \\
\hline $\begin{array}{c}\text { Dietzia } \\
\text { natronolimnaea } \\
\text { HS-1 }\end{array}$ & & $\begin{array}{l}\text { canthaxanthin } \\
(2.87 \mathrm{mg} / \mathrm{L})\end{array}$ & 3.06 & $\sim 0.9$ & [77] \\
\hline
\end{tabular}

Likewise, pulcherrimin is a red pigment belonging to cyclodipeptides, characterized for its strong biological properties, including antibacterial, antifungal, antitumoral, and anti-inflammatory activities [92]. Türkel et al. [93] mentioned that microorganisms producing pulcherrimin can be effectively used as biocontrol agents against various postharvest pathogens causing fruit and vegetable spoilage, due to the antimicrobial activity of the pigment [93]. Pulcherrimin production has been identified as a metabolite of the yeast Metschnikowia pulcherrima, but it has been poorly investigated until now [94,95]. M. pulcherrima is able to metabolize various carbon sources, including galactose and glucose, but it cannot hydrolyze lactose [95]. This indicates that hydrolyzed whey lactose could be employed as fermentation feedstock for pulcherrimin production. Alternatively, whey lactose could also be utilized by Bacillus licheniformis, which is able to assimilate lactose and has presented the highest pulcherrimin production of $331.7 \mathrm{mg} / \mathrm{L}$ under optimized culture conditions [92].

Similarly, flavor and aroma compounds constitute another essential category for the food industry. Those compounds are widely used in order to manufacture attractive products to consumers. 
Chemical synthesis is an inexpensive method for the production of aroma compounds; however, the derived products cannot be applied in foods. On the other hand, the traditional extraction of aroma compounds from plants exhibits disadvantages regarding low yields and high production cost. In this context, fermentation processes could provide an alternative way for the production of natural aroma compounds. Few studies have focused on cheese whey valorization for the production of fragrances. Several yeast strains were isolated and screened for the production of 2-phenylethanol, an aroma compound found in rose petals, using a whey medium supplemented with sugar beet by-products (molasses, thick juice, or sludge) and L-phenylalanine as a precursor. Among all strains, the highest concentration of $3.3 \mathrm{~g} / \mathrm{L}$ was achieved by a Saccharomyces. cerevisiae yeast strain [96]. The strain Metschnikowia pulcherrima is also a promising producer of 2-phenylethanol. Currently, there is not any published study using whey; however, utilization of simulated grape juice medium resulted in significant production of 2-phenylethanol (14 g/L) [97]. Other aroma compounds, including 2-phenylethanol, have been identified at low concentrations in a whey-glucose substrate fermented by the yeast Wickerhamomyces pijperi. In total, twelve aroma compounds such as isobutanol, isoamyl alcohol, 2-phenylethanol, acetaldehyde, ethyl acetate, propyl acetate, isobutyl acetate, isoamyl acetate, ethyl butyrate, ethyl propionate, ethyl hexanoate, and ethyl benzoate have been determined [98].

\subsubsection{Bacterial Cellulose}

Bacterial cellulose is a microbial polysaccharide presenting improved water holding capacity, hydrophilicity, high degree of polymerization, mechanical strength, crystallinity, porosity, and purest fiber network, compared to plant cellulose. Several food applications have been developed for bacterial cellulose, since it has been characterized as a "generally recognized as safe" (GRAS) food by the US Food and Drug Administration (FDA). It has already been applied in ice-creams as a rheology modifier, in confectionery products as a fat replacer, as artificial meat for vegetarian consumers, as a stabilizer of emulsions, or as an immobilization carrier of probiotics and enzymes [99].

Bacterial cellulose is synthesized from several Acetobacter species. Gluconacetobacter xylinus (formerly known as Acetobacter xylinum) is one of the most studied species because of its ability to produce high bacterial cellulose concentrations using various substrates [100]. The implementation of inexpensive renewable resources and agro-industrial wastes as fermentation media could alleviate the high cost for bacterial cellulose production that hinders large scale manufacture. Bacterial cellulose production has been previously studied using by-products deriving from biodiesel and food industries, such as sunflower meal, glycerol, confectionery wastes, citrus by-products, grape pomace, and discarded currants, among others [100-104]. High yields (up to $15.2 \mathrm{~g} / \mathrm{L}$ ) of bacterial cellulose were obtained from synthetic sucrose, glucose, and fructose media [105-107]. Agro-industrial substrates such as molasses, fruit juices, or aqueous extracts from citrus residues resulted in production yields of up to $7.8 \mathrm{~g} / \mathrm{L}[101,105]$. In the case of lactose utilization, there are only a few studies dealing with bacterial cellulose production (Table 2). Tsouko et al. [100] demonstrated that synthetic lactose was not efficiently metabolized from Komagataeibacter sucrofermentans DSM 15973, yielding up to $1.6 \mathrm{~g} / \mathrm{L}$ bacterial cellulose [100]. Likewise, Mikkelsen et al. [108] reported a final bacterial cellulose production of $0.1 \mathrm{~g} / \mathrm{L}$ by G. xylinus ATCC 53524 grown on galactose [108]. Similarly, other studies have agreed that cheese whey does not support significant bacterial cellulose production by A. xylinum 10821, A. xylinum 23770 [109], and isolated from Kombucha tea G. sacchari [110]. This could be attributed to the fact that the gene that encodes $\beta$-galactosidase is not expressed by bacterial cellulose producers. Battad-Bernardo et al. [111] produced a mutant of A. xylinum by inserting lacZ gene, thus allowing the hydrolysis of lactose [111]. The mutant strain was able to produce $1.82 \mathrm{~g} / \mathrm{L}$ bacterial cellulose in a whey-based substrate [111]. Another approach lies in the pre-treatment of cheese whey through enzymatic catalysis. In this way, Salari et al. [112] improved bacterial cellulose production ( $3.55 \mathrm{~g} / \mathrm{L})$ by G. xylinus PTCC 1734 using an enzymatically-hydrolyzed cheese whey [112]. In another study, around $5.4 \mathrm{~g} / \mathrm{L}$ of bacterial cellulose was produced by the isolated Gluconacetobacter. sucrofermentans B-11267 strain on untreated cheese whey [113]. 
Table 2. Bacterial cellulose (BC) production using lactose or lactose derivatives.

\begin{tabular}{cccc}
\hline Microorganism & Carbon Source & BC (g/L) & Reference \\
\hline K. sucrofermentans DSM 15973 & Synthetic lactose & 1.6 & {$[100]$} \\
G. xylinus ATCC 53524 & Synthetic galactose & 0.1 & {$[108]$} \\
A. xylinum 10821 & Cheese whey & 0.04 & {$[109]$} \\
A. xylinum 23770 & Cheese whey & 1.13 & {$[109]$} \\
G. sacchari & Cheese whey & 0.15 & {$[110]$} \\
A. xylinum mutant & Cheese whey & 1.82 & {$[111]$} \\
G. xylinus PTCC 1734 & Hydrolyzed cheese whey & 3.55 & {$[112]$} \\
G. sucrofermentans B-11267 & Cheese whey & 5.4 & {$[113]$} \\
\hline
\end{tabular}

\subsubsection{Functional Food Additives}

Development of functional food ingredients is of paramount significance for the food industry, driven by the rising demand to manufacture food products that confer health benefits. Among others, several research studies have been conducted focusing on the production of value-added compounds from mushrooms and microalgae. Still, the full potential of cheese whey was not fully exploited in these cases.

Mushrooms are known for their exceptional functional properties, primarily due to their polysaccharide content [114]. Mushroom fruiting bodies contain a significant amount (35-70\%) of non-digestible — and to lesser extent, digestible—carbohydrates. Chitin, $\beta$-glucans, glucose, mannitol, and glycogen are the main component carbohydrates [115]. These components serve as the dietary fiber fraction, found mostly in the fungal cell wall, and possess many beneficial effects on human health, including antitumor, hepatoprotective, antimicrobial, prebiotic, antioxidant, hypoglycemic, and hypolipidemic activity [114]. Various mushroom species have been studied for the production of polysaccharides [116,117]. However, the mushrooms belonging to the genus of Pleurotus sp., Ganoderma lucidum, and Lentinula edodes (shiitake mushroom) have been most extensively studied.

Many Pleurotus species have demonstrated biological effects, such as immunostimulating and antitumor activity. More specifically, P. ostreatus and P. eryngii contain several water-soluble and non-soluble $\beta$-glucans with prebiotic properties [118]. Recently, Velez et al. [119] showed that the mycelium of $P$. djamor was rich in ergosterol and $\beta$-glucans, presenting also high antioxidant activity when grown in cheese whey supplemented with sodium selenite [119]. It was suggested that the lactose-free mycelium, rich in bioactive compounds, is an appropriate supplement for consumers with lactose intolerance. In the case of cheese whey fermentation by $P$. sajor-caju, mycelium biomass was found rich in carbohydrates (arabinose, mannose, and $\mathrm{N}$-acetylglucosamine) and proteins $(39.2 \%)$ containing high amounts of essential amino acids, such as lysine, leucine, threonine, and phenylalanine [120]. Likewise, P. osteatus exhibited higher contents of water-soluble polysaccharides and trace elements, such as calcium, phosphorus, potassium, sodium, and magnesium, when cultivated in whey permeate rather than in synthetic medium [121]. A previous study has shown that cheese whey could also be efficiently utilized in solid state fermentations by P. ostreatus [122].

Lentinula edodes produces a polysaccharide, namely lentinan, which is the most studied immunomodulating polysaccharide and commercially available in pharmaceutical products. Glycoproteins from this mushroom have been characterized for their antitumor activity [123]. Few reports of Lentinula edodes cultivation in cheese whey, have shown that the mycelium is rich in water-soluble polysaccharides and minerals (calcium and potassium) showing also high antioxidant capacity, which suggests that dairy by-products could be utilized as a growth substrate for the cultivation of L. edodes [124-126].

Few studies have included the optimization of culture conditions using cheese whey for the production of polysaccharides from Ganoderma lucidum, indicating its ability to be used as an alternative fermentation medium [127-129]. This mushroom has been characterized as "the mushroom of immortality" in Asian countries, because of the existence of 400 different bioactive compounds 
in mycelia and fruiting body. It is recognized as an alternative adjuvant in the treatment of leukemia, carcinoma, hepatitis, and diabetes, and its bioactive compounds consist of triterpenoids, polysaccharides, nucleotides, sterols, steroids, fatty acids, and proteins, among others [130]. Recently, G. lucidum polysaccharides were applied to the production of microcapsules using whey proteins as wall material. This product showed better stability and controlled release ability [131]. This is a representative paradigm of polysaccharide production from medicinal mushrooms, and subsequent product development through encapsulation, in the framework of an integrated cheese whey biorefinery.

Another less studied, yet highly valued, edible mushroom is Morchella sp. It is a delicious and expensive mushroom containing heteroglycans with antitumor and hypoglycemic properties [118]. Many species of Morchella sp. have demonstrated high polysaccharide content after cultivation on agro-industrial substrates [132]. Nevertheless, the use of cheese whey as substrate for Morchella production is still unexplored. Kosaric and Miyata reported, for the first time in 1981, that several Morchella species, such as M. crassipes, M. esculenta, M. deliciosa, M. rotunda, and M. angusticeps, were able to grow on partially deproteinized cheese whey. $M$. crassipes produced the highest biomass of $20 \mathrm{~g} / \mathrm{L}$, which contained $45 \%$ protein, many essential amino acids, and high proportion of unsaturated fatty acids, such as linoleic acid (55.7\%) and oleic acid (13\%) [133].

In a similar way, microalgae species are known for their ability to accumulate high quantities of polysaccharides, proteins, polyunsaturated fatty acids, and carotenoids—-thus, they are considered superior candidates for food supplements [134]. Spirulina and Chlorella are blue-green microalgae species exhibiting various health benefits, including antiviral, anti-inflammatory, and antitumor properties [135]. Cultivation of microalgae in cheese whey has been considered a feasible alternative for cost-effective production of microalgal biomass production [136]. More specifically, the mixotrophic culture of Chlorella vulgaris in a medium supplemented with hydrolyzed cheese whey demonstrated improved biomass production. This was attributed to the presence of growth-promoting nutrients in cheese whey [136]. Spirulina platensis presented higher carbohydrate, carotenoid, and chlorophyll contents when the substrate was supplemented with cheese whey [137,138]. Girard et al. [139] substituted a significant quantity $(40 \%, v / v)$ of the basal medium with whey permeate, which resulted in higher biomass production by the fresh water green algae Scenedesmus obliquus under mixotrophic conditions [139]. The significance of Scenedesmus obliquus is on its enzymatic extracts, which contain several amino acids essential for human diet, presenting also antioxidant and antiviral activities [140,141].

\section{Whey Proteins: Research Insights and Trends}

The increasing global demand for natural ingredients in food manufacturing has led to significant research interest on whey proteins (WP) to manufacture products with desirable characteristics. Whey proteins exhibit physicochemical properties resulting in enhanced texture and quality of end-products, regarding structural and rheological functions $[142,143]$. Surface-active components, texture modifiers, foaming and gelling agents, thickening agents, emulsifiers, and other bioactivities, among others, indicate targeted application of WP as active ingredients [144-146] (Figure 1).

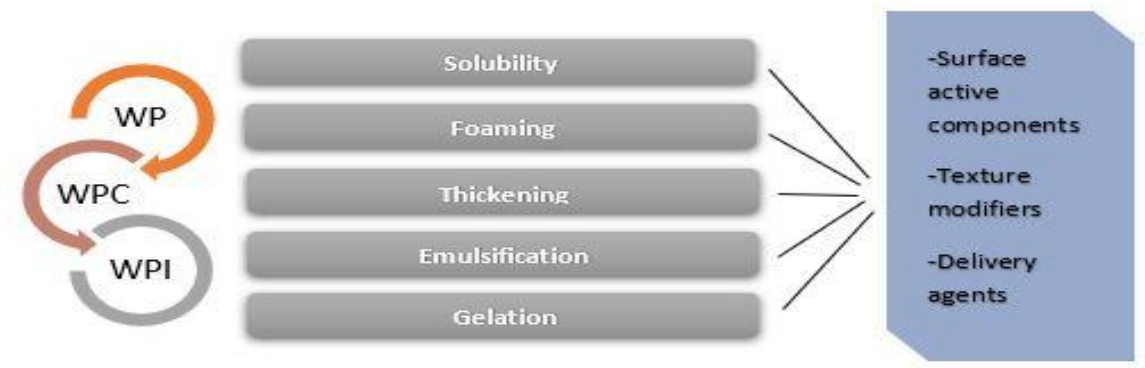

Figure 1. Technological functions of whey protein (WP), whey protein concentrate (WPC), and whey protein isolate (WPI) in food applications. 
WPs can develop macro-, micro-, and nano-structures with numerous promising food applications, such as vehicle carrying for various bio-compounds, flavors, or nutrients (Figure 2). Hence, the emerging development of WP processing techniques could enable further applications that will be directed towards value-added products. In an analogous approach, the following sections will elaborate the most promising applications of cheese whey proteins. The development of edible films and coatings, nanoparticles like hydrogels, and the production of whey protein bioactive peptides as potential nutraceuticals will be further described. Within this context, novel approaches on WP implementation could foster the spectrum of end-use applications that could be incorporated in the development of a holistic process for cheese whey valorization.

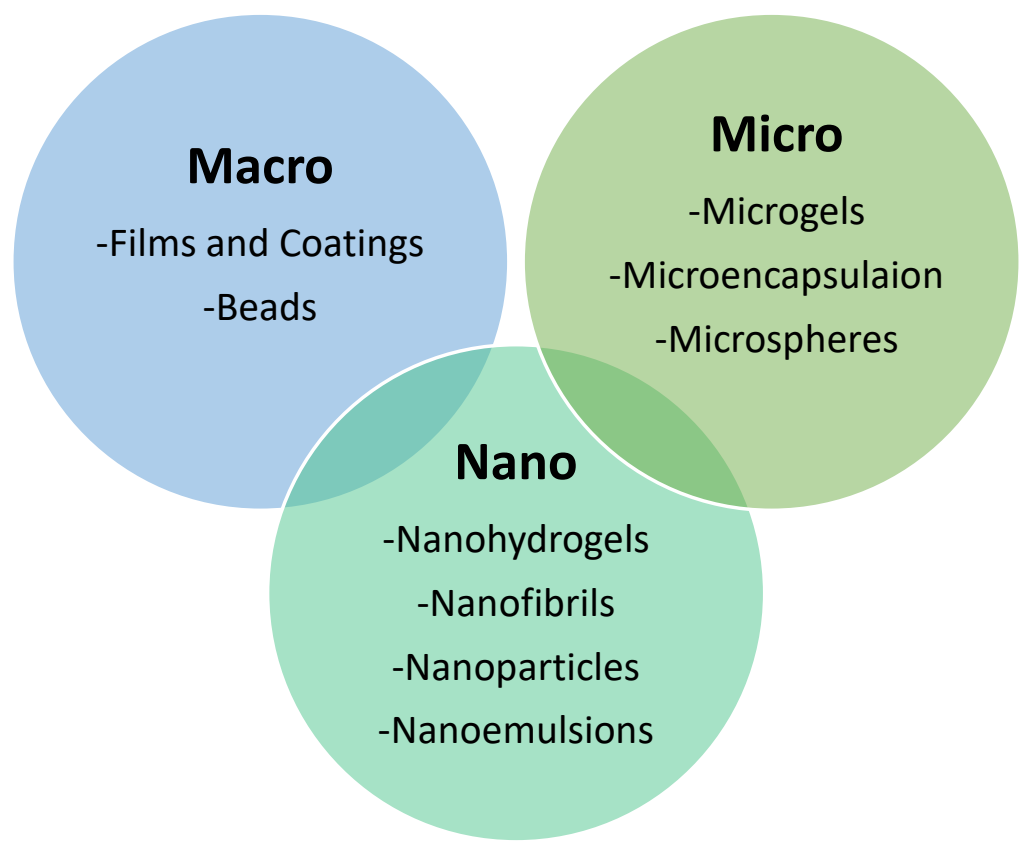

Figure 2. Whey protein systems used as delivery vehicles for bioactive ingredients in food.

\subsection{Edible Films and Coatings}

\subsubsection{Recent Strategies for Improved Technical and Functional Properties}

The flourishing demand for eco-friendly active packaging has stimulated research on bio-based packaging. The use of WP for the formation of edible films and coatings has drawn scientific interest, as they are produced from an abundant and renewable material compared to the synthetic counterparts. Among biopolymers used to fabricate edible films, WP exhibits diverse and distinctive technological properties. More specifically, WP can form transparent films and coatings with improved mechanical and barrier properties compared to polysaccharide-based films, indicating them as potential candidate for numerous applications (e.g., high barrier properties like oxygen and volatiles under low moisture conditions) [147]. WPs are usually employed in food application as whey protein concentrates (WPCs) and whey protein isolates (WPIs), induced by the technological advances of whey processing, that convey enhanced functionality (Table 3). 
Table 3. Edible films formation from whey protein isolate (WPI) and whey protein concentrate (WPC) and their functional features.

\begin{tabular}{|c|c|c|c|}
\hline Substrate & Promoting Compound & Functionality & Reference \\
\hline \multirow{12}{*}{ WPI } & Almonds, walnut oil & Water barrier improvement & [148] \\
\hline & $\begin{array}{l}\beta \text {-cyclodextrin/eugenol, } \\
\text { carvacrol }\end{array}$ & Antimicrobial component delivery & [149] \\
\hline & Lysozyme & Antimicrobial component delivery & [150] \\
\hline & Montmorillonite nanoplatelets & Oxygen barriers improvement & [151] \\
\hline & $\begin{array}{l}\text { Montmorillonite clay } \\
\text { nanoparticles }\end{array}$ & Thermal stability, water vapor permeability & [152] \\
\hline & $\begin{array}{l}\text { Nanocrystalline cellulose, } \\
\text { transglutaminase }\end{array}$ & Improved mechanical properties & [153] \\
\hline & Oat husk nanocellulose & $\begin{array}{c}\text { Enhanced tensile strength, solubility, } \\
\text { decreased elongation at break and moisture } \\
\text { content, decreased transparency and water } \\
\text { vapor permeability }\end{array}$ & [154] \\
\hline & Pullulan, montmorillonite & $\begin{array}{l}\text { Improve the mechanical properties, thermal } \\
\text { properties, and water resistance }\end{array}$ & [155] \\
\hline & $\begin{array}{l}\text { Sodium laurate-modified } \\
\mathrm{TiO}_{2} \text { nanoparticles }\end{array}$ & $\begin{array}{l}\text { Water vapor permeability decreased, tensile } \\
\text { strength increase, decreased transparency }\end{array}$ & [156] \\
\hline & Starch & Water vapor permeability, microstructure & [157] \\
\hline & Zein & $\begin{array}{l}\text { Enhanced water solubility and } \\
\text { heat-sealablity }\end{array}$ & [158] \\
\hline & Zein nanoparticles & $\begin{array}{l}\text { Improved moisture barrier and } \\
\text { mechanical properties }\end{array}$ & [159] \\
\hline \multirow{8}{*}{ WPC } & Cinnamon essential oil & Antimicrobial & [160] \\
\hline & Glucerol, pullulan, beeswax & $\begin{array}{l}\text { Improved color indices, diminished water } \\
\text { solubility and water vapor permeability, } \\
\text { and increased tensile strength }\end{array}$ & [161] \\
\hline & Immunoglobulins & $\begin{array}{l}\text { Increase stickiness, adhesion, and tensile } \\
\text { strength of the films }\end{array}$ & [162] \\
\hline & Liquid smoke & $\begin{array}{l}\text { Antimicrobial/improved mechanical } \\
\text { properties }\end{array}$ & [163] \\
\hline & Montmorilonite, lycopene & $\begin{array}{l}\text { Antioxidant activity and UV-vis light } \\
\text { protection/mechanical } \\
\text { properties improvement }\end{array}$ & [164] \\
\hline & $\begin{array}{l}\text { Rosmarinic acid, carnosol, } \\
\text { carnosic acid }\end{array}$ & & \\
\hline & $\begin{array}{l}\text { Sodium alginate, pectin, } \\
\text { carrageenan, locust been } \\
\text { gum/L. rhamnosus }\end{array}$ & $\begin{array}{c}\text { Enhanced survival during drying and } \\
\text { storage, reduced film water } \\
\text { vapor permeability }\end{array}$ & [165] \\
\hline & Sunflower, beeswax & Water vapor permeability & [166] \\
\hline
\end{tabular}

Incorporation of different additive compounds on whey protein-based films to improve their natural, technical and functional properties has lately attracted significant attention [167]. For instance, immunoglobulins (Ig) incorporated into whey protein films improved adhesion and strength [162], but also yielded more transparent and clear films. Moreover, the authors stated that embedding Ig in whey protein matrices resulted in the protection from rapid proteolysis, thereby sustaining their activity in the gastrointestinal track (GIT). Other modifications have been also used to improve whey protein films, including, for instance, the inclusion of lipid components to improve the moisture ability of such 
films. Almond and walnut oils were employed, along with WPI, leading to a reduction of the surface hydrophilic character of films [148]. Sunflower oil was also used with WPC, resulting in a reduction of water vapor permeability [166]. An emerging strategy to further enhance technical and functional properties of these films, thus improving the compatibility of polymers, lies in the incorporation of nanomaterials $[152,156]$.

Likewise, the use of edible-coated nanosystems has also been considered as a novel approach for food preservation. Findings have lately suggested that novel WPI-based nanocomposites can be part of multilayer flexible packaging films, thus holding great potential to even replace well-established fossil-based packaging materials to support certain mechanical properties during storage $[151,153,155,163]$. Alternative biomaterials, have also been recently proposed for potential uses in foodstuff applications, via the production of nanocomposites from WPCs activated with lycopene and montmorillonite nanoparticles $[164,168]$. In another work, WPI nanocomposite films properties were reinforced with oat husk nanocellulose [154]. Evidently, novel perspectives are encountered in the development of novel packaging materials.

Notwithstanding, along with the increase of whey protein edible film generation, it is crucial to overcome specific disadvantages of these films in terms of mechanical features and moisture barrier properties. This could be alleviated by blending films and coatings with various plasticizers. As an example, Basiak et al. (2017) used various starch/whey proteins mixtures and studied their effect on transport properties of the produced films [157].

Likewise, several studies have suggested the use of plasticizers and crosslinking on the formulation of films, as a potential technology for novel food packaging, to improve water resistance, mechanical and barrier characteristics [152], while diversified blends, using different ratios of pullulan or sugars like trehalose, have been also recently proposed as plasticizers of whey protein films [161,169].

\subsubsection{Delivery Agents of Bioactive Compounds}

The deployment of specific active compounds with antimicrobial or natural antioxidant features, into the matrix of whey protein isolate formation, remains a field of significant importance $[170,171]$. Improved quality and safety control, along with extended shelf life, of the products, are among the main advantages reported by the use of such complex films, implying their potential application for food wrapping [150,160,172].

Another evolving aspect for bioactive whey protein-based films and coatings was presented via the incorporation of functional bacteria. The use of edible films and coatings as carriers of living microorganisms constitutes a challenge. Microorganisms should remain in high concentrations to exert beneficial effects (antimicrobial or probiotic) without affecting the mechanical or sensory properties of the product. Novel approaches using whey edible films and coatings have resulted in enhanced cell survival. WPC was evaluated, along with several selected biopolymers, as a potential vehicle to investigate L. rhamnosus GG survivability [165]. To date, only a few reports exist about probiotic activity in edible films and coatings from whey [164]. The possibility of implementing whey protein formations as a carrier matrix for viable probiotics could potentially result in better survival rates during storage and consumption, thereby promoting novel food applications.

\subsection{Whey Protein Hydrogels}

\subsubsection{Formulations and Structural Characteristics}

Whey proteins have the ability to form polymeric three-dimensional networks, including hydrogels systems $[173,174]$, and further combine them into nanoparticles. For instance, $\beta-L G$, which is the main component of whey protein isolate, is also the responsible particle for the main functional properties. These hydrogels are considered as unique delivery systems, since $\beta$-LG nanoparticles are able to bind to hydrophobic compounds. The gel formation process of WP starts when proteins are 
partially denaturated above critical temperature, leading to the formation of the three-dimensional molecule structure.

Whey protein gels can be temperature-induced by either cold- or heat-set mechanisms $[175,176]$, acid-induced [177], or even enzyme-induced [143,156]. Heat-induced gelation of whey protein is irreversible; therefore, gels are being extensively studied as potential candidates for the preparation of fluid gels without additives $[178,179]$. Recent studies have reported the preparation of whey protein aggregates through protein crosslinking and building blocks of cold-set gels, thus protecting substances from high temperatures $[180,181]$. Cold gelation is emerging as a rising method to formulate whey protein microgels [174]. This characteristic renders them as promising candidates to design functional products, where heat- or acid-sensitive nutraceuticals are encapsulated.

Structural characterization of hydrogels is crucial, in order to evaluate their potential in food applications. The rheology of whey protein isolate and casein micelles (MC) mixtures upon heating has been evaluated, indicating that WPI binds to MC and strengthens the junctions of the MC network [176]. Likewise, different mixtures, including starch, rice, or other polysaccharides, or other proteins combined with WPI are currently being studied, aiming to improve the structural and functional properties (e.g., strength, viscosity) of protein solutions [176,182].

The stability and strength of the protein-gel network is evidently associated with the designated applications in food and biomaterials. Characterization of WP gelation profiles has been recently studied; however, the main challenge remains in the production of effective WP microgel systems to overcome brittleness and susceptibility to syneresis [183]. Research is focusing on the ability of WP to form hydrogels that entail specific structural and sensory characteristics for targeted food products like yoghurt, ice cream, bakery products, desserts, and meat products [182]. Understanding the interactions of whey with other biopolymers is crucial in the sense of novel functional food properties. Therefore, the interactions of mixed systems of whey with other biopolymers-such as pectin, $\mathrm{k}$-carrageenan, xanthan, and basil seed gum-have been studied [184-187]. These synergistic interactions, leading to the production of stronger gels, could be beneficial in many food formulations such as dairy and dessert products.

\subsubsection{Emerging Techniques for Food Applications}

Whey proteins have been employed for microencapsulation to enhance the viability of potential probiotic microorganism by using high internal phase emulsions stabilized with WPI microgels [188,189]. Whey protein hydrogels have shown improved survivability of probiotic bacteria under heat treatment at various storage conditions and along GIT passage [190]. Furthermore, numerous kinds of bio-compounds have also been encapsulated, like tryptophan, riboflavin, and peptides from whey protein microbeads [191], vitamins [192], essential oils [193], curcumin [194], lactoferrin [195], and nutraceuticals like folic acid [196]. WPI nanoparticles have been used for $\alpha$-tocopherol and resveratrol encapsulation as protein-based carriers for hydrophobic components [197]. WPHs have also been successfully applied for encapsulation of water-soluble nutraceuticals [198].

Incorporation of micro- and nanoparticles as carriers of bioactive compounds entails the controlled delivery of these compounds, thus improving nutritional aspects of functional foods. In addition, enhancement of anticancer activity has been also lately reported as a result of controlled release of lycopene loaded in WPI nanoparticles [199]. Actually, various whey-based matrices have been studied in nutritional applications, incorporating different kind of bioactive compounds [191,200], while the use of whey proteins together with fermentable dietary fibers (such as k-carrageenan), has been also recently reported as a suitable vehicle for the inclusion of proteins and peptides in gelled food products [184].

Likewise, production of whey protein nanofibrils, as novel nanocarriers to enhance the solubility of bioactive compounds and control their release into GIT, constitutes an emerging challenge. Within this context, Alavi et al. [201] employed k-carrageenan, in combination with whey protein aggregates (WPA), in order to control the release of curcumin in the upper gastrointestinal tract [201]. In a similar 
study, Mohammadian et al. [202] observed the high ability of whey protein nanofibrils to bind curcumin, resulting in a significant release in simulated gastric and intestinal fluids [202]. The authors suggested that whey protein nanofibrils could be used in the formulation of food, drinks, and beverages as a multifunctional carrier for bioactive compounds. The produced hydrogels protected curcumin and proved to be effective for colon-specific delivery. Besides the approach of whey protein gel, proteins can independently assemble to form fibrillary systems. These nanosystems convey new insight into food science applications, exhibiting important functional characteristics, including emulsification and gelation properties, increased viscosity competence, and foam stabilization properties at relatively low protein concentration [203-205].

On top of that, the fabrication of various types of nutraceutical-carrying nanosystems has recently attracted special interest. Nutraceuticals delivery, to beyond water-soluble compounds, could be achieved by the development of novel whey protein hydrogels. In the frame of that, Hashemi et al. [206] proposed the development of gels, through combination of whey protein solution with nanostructured lipid carriers (NLCs) of fat-soluble compounds [206]. Likewise, whey proteins have been described as effective carriers of lipophilic nutraceuticals and scientific attention has been ascribed to the formation of whey-derived products with inhibitory activity on lipid peroxidation. Zhu et al. [207] used surface hydrophobicity properties to form nanocomplexes consisting of whey proteins and fucoxanthin [207]. Prevention of oxidative degradation of carotenoids or other phenolic compounds has been reported, after the inclusion of the aforementioned compounds into WPI emulsions [208-210]. Moreover, increased bioavailability of astaxanthin in Caco-2cell models on whey protein nanodispersion was recently demonstrated [211].

Whey protein nanostructures represent a promising area of food research following their definition as GRAS materials [212]. WPI exhibit core-shell structures similar to natural biopolymers, able to entrap hydrophobic compounds to a great extent. Nanostructural delivery systems are considered substantial approaches to improve biological performance of bioactive compounds. Thus, novel processing techniques are recently employed to modify structural (physicochemicals) and functional properties, demonstrating significant potential for food manufacture applications.

Likewise, pulsed electric field [213], ultrasound [214], or ultraviolet radiation [215] as non-thermal approaches have been shown to exhibit little or no change on the nutritional content. Nevertheless, the electrospinning technique is currently being studied as an emerging advancement for the production of food-grade nanofibers from WP [216]. Electrospinning has been employed to produce micro- to nano-scale fibers as a carrier system to evaluate their potential utilization in food [217]. The ability to generate nanofibers from whey proteins exhibits an opportunity to exploit their inherent benefits, along with the desirable attributes of nanofibers. In addition, incorporation of active compounds and their controlled and monitored subsequent release can be also also achieved [218]. Recent reports dealing with novel electrospun fibers from different blends of WPI have highlighted the advantages of the process, as well as their potential uses in many food related applications [219]. The challenges associated with the development of specific protein fibers correlate with the subsequent specific application, considering that fiber stability in aqueous media and mechanical strength, constitute the most frequent impediments to be challenged [220].

\subsection{Whey Protein as a Source of Nutraceuticals}

\subsubsection{Nutritional Aspects of Whey Proteins}

Whey proteins are considered functional nutraceuticals, since they exert remarkable biological activities. They mainly consist of lactoglobulin, lactalbumin, bovine serum albumin, lactoperoxidase, lactoferrin, glycomacropeptide (GMP), and immunoglobulins [6]. From a nutritional aspect, whey proteins are superior to other proteins, such as caseins, since their amino acid profile includes a high proportion of essential branched-chain amino acids (BCAAs) [221,222], such as leucine, isoleucine, and valine, which are crucial in blood glucose homeostasis, metabolism, and neural function [223-225]. 
Recently, a Leucyl-Valine peptide in whey protein hydrolysate was found to be able to stimulate heat shock proteins response in rats [226]. Heat shock proteins are known to participate in stabilization and restoration of damaged proteins induced by various stress, resulting in maintaining normal cellular function [227]. Whey proteins also contain significant amount of sulfur amino acids, such as methionine and cysteine, which are reported to act as nutraceuticals [228-230]. In general, cheese whey proteins are well-documented as an important source of essential amino acids by means of biologically active peptides. These peptides are considered to be inactive within the sequence of the parent protein, but can be released from whey proteins in sufficient quantities under specific procedures.

Approximately $50 \%$ of whey protein is beta-lactoglobulin. Results from a recent study indicate that the Se- $\beta$-LG complex presents antitumor activity [231]. The authors also used $\beta$ - LG nanoparticles as nutraceutical carriers to elevate transepithelial permeation, mucoadhesion, and cellular uptake. In parallel, non-covalent interactions between $\beta-L G$ and polyphenol extracts of teas, coffee, and cocoa have been reported at $\mathrm{pH}$ values of the GIT [232]. The health-promoting effect of cheese whey protein is primarily attributed to their antioxidant properties $[233,234]$ and to their promoting effect on cellular antioxidant pathways [16]. Furthermore, modified products of whey peptides have been shown to increase the antioxidant capacity of the plasma, reducing the risk of certain heart diseases [235]. BSA is another important whey protein, with several drug binding sites, that has been applied as a matrix for nanoparticle-based drug delivery [236].

A broad range of physiological, medical, and nutritional values have been assigned to whey protein and its derivatives, as an excellent source of bioactive peptides. These biomolecules are defined as specific protein fragments that positively influence health and have a beneficial impact on body functions, as summarized in Table 4. Bioactive whey components have been widely studied, revealing various capacities to modulate adiposity, cardiovascular, and gastrointestinal systems $[237,238]$.

Table 4. Whey protein edible film formation from whey protein isolate (WPI) and whey protein isolate (WPI) and their functional features.

\begin{tabular}{|c|c|c|c|}
\hline Biological Function & Formulation & Test Model & References \\
\hline \multirow{2}{*}{ Anti-diabetic } & Whey protein hydrolysate & Insulin-resistant rats & [239] \\
\hline & Whey protein & Human & [240] \\
\hline Anti-inflammatory & $\beta$-lactoglobulin hydrolysate & In vitro & [241] \\
\hline Anti-hypertensive & Whey protein concentrate & In vitro & [242] \\
\hline \multirow{2}{*}{ Anti-obesity } & Whey protein concentrate & Obese human & [243] \\
\hline & Whey protein concentrate & Obese human & [244] \\
\hline Antitumor & $\beta$-lactoglobulin hydrolysate & In vitro & [231] \\
\hline Benefit in resistant exercise & Hydrolyzed whey protein & Human & [245] \\
\hline Blood pressure lowering & Whey protein hydrolysate & Rats & [246] \\
\hline Dermatoprotective & Whey peptide & Mice & [247] \\
\hline GI motility & $\begin{array}{l}\text { Whey protein concentrate, Whey } \\
\text { protein Hydrolysate }\end{array}$ & Mice & [248] \\
\hline Gut and energy homeostasis & Whey protein isolate & Mice & [249] \\
\hline Hypolipidemic & Whey protein & Mice & [234] \\
\hline $\begin{array}{l}\text { Muscle protein } \\
\text { synthesis/glycogen }\end{array}$ & Whey protein hydrolysate & Mice & [226] \\
\hline Osteroprotection & $\begin{array}{l}\text { Whey protein derived dipeptide } \\
\text { Glu-Glu }\end{array}$ & In vitro & [250] \\
\hline Oxidative stress & Whey protein concentrate & Mice & [251] \\
\hline $\begin{array}{l}\text { Oxidative stress/Glucose } \\
\text { metabolism }\end{array}$ & Whey protein isolate & $\begin{array}{l}\text { Overweight/obese } \\
\text { patients }\end{array}$ & [252] \\
\hline Phenylketonouria therapy & Whey protein glycomacropeptide & Human/mice & [253] \\
\hline Recovery of muscle & Whey protein hydrolysate & Human & [254] \\
\hline functions & Whey protein & Human & [255] \\
\hline Sceletical muscle protection & Whey protein hydrolysate & Rats & [256] \\
\hline
\end{tabular}




\subsubsection{Generation of Bioactive Peptides}

Bioactive peptides have attracted significant research and consumer interest, resulting from the potential application in the fortification of products marketed as functional foods or other products for dietary interventions. They can be produced by the following ways: Enzymatic hydrolysis by digestive enzymes during gastrointestinal transit, proteolytic activity of starter cultures during milk fermentation, and proteolytic activity of microorganisms or plants (Figure 3) [257-259]. Microbial fermentation remains an easy and cheap way for generating diverse biopeptides through a safe microbial proteolytic food system. Lately, studies have reported that enzymatic hydrolysis of cheese whey proteins results in different biomolecules with antioxidant properties [260], anticancer [261], and even opioid functions [251]. Alvarado et al. [242] studied the production of antihypertensive peptides from whey protein hydrolysate $(<3 \mathrm{kDa})$ and encapsulated them in order to evaluate angiotensin-converting enzyme activity (ACE\%) during GIT digestion [242]. The results revealed about a 10\% increase of ACE activity by the released peptides.

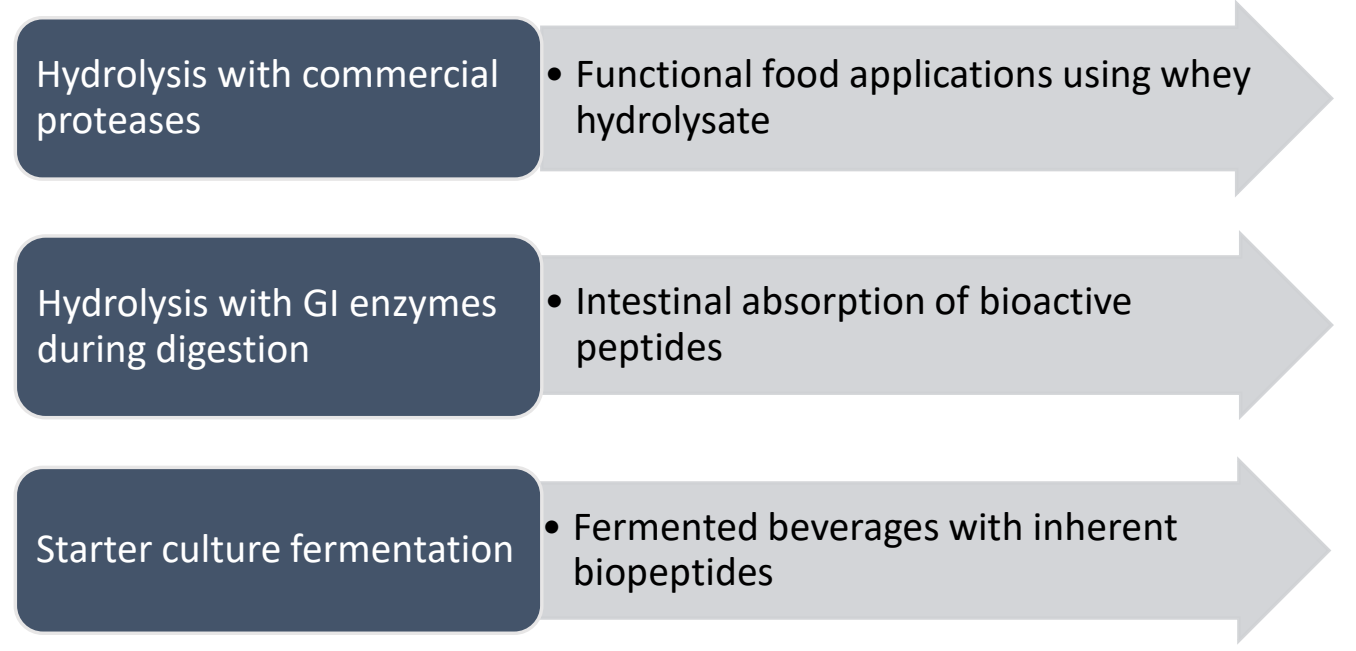

Figure 3. Production methods of bioactive peptides derived from whey proteins and their utilization potential.

All three major forms of cheese whey protein and derivatives (concentrates, isolates, and hydrolysates) encompass unique attributes for nutritional, biological, and food ingredient applications. Recent studies have reported that hydrolysates can maximize nutrient delivery to muscle protein anabolism, presenting higher bioactivity [262-264]. WPHs have been reported for insulinotropic effects [265]. As stated above, many biopeptides are encrypted within their native protein sequences and can thus be liberated only by protein fragmentation [266].

As far as it concerns the industrial production of whey pure protein fractions, techniques of membrane filtration, such as microfiltration and/or ultrafiltration, are employed to enrich whey food ingredients (i.e., whey hydrolysates) $[267,268]$. Herein, the challenge remains in terms of stability of these fractions under different downstream processes and gastrointestinal phases.

Regardless the scientific achievements, application of bioactive peptides from whey that exert beneficial effect in human nutrition is in its infancy, as several challenges exist in the discovery and identification of bioactive peptide both in vitro and in vivo [269]. Novel bioprocessing strategies for bioactive peptides have been developed as food peptidomics, food proteomics, and nutrigenomic $[270,271]$. Evidently, an omics approach and bioinformatics could elucidate further development on the application of bioactive peptides [272].

The versatile end applications of whey proteins render them compounds of paramount importance, to be further employed within the frame of integrated biorefineries concepts. However, further research is required to elucidate the underlying mechanisms on food fortification and in human nutrition. 
Nonetheless, sedimentation and recovery of protein fraction, separation of individual whey proteins and derivatives synthesis have great potential to be incorporated in an integrated process and further enhance feasibility by obtaining end-products of high-value.

\section{Current Integrated Biorefineries}

As per the IEA Bioenergy Task 42 definition, "Biorefinery is the sustainable processing of biomass into a spectrum of marketable products (food, feed, materials, chemicals) and energy (fuels, power, heat)" [273]. Thus, to ensure the sustainability and cost-effectiveness of a biorefinery, it is indisputable that a multitude of viable end-products should be manufactured. The development of a biorefinery concept should also employ all potential streams of the onset feedstock under the concept of circular economy and zero waste generation, thus encompassing all three pillars of sustainability, i.e., environment, society, and economy [273]. Integration of biorefining processes annexed to existing manufacturing plants for on-site valorization would alleviate the industry and stake holders' concerns about investing in facilities and equipment that would be depreciated. Another key parameter during the configuration of biorefinery concepts is the complex and heterogenous nature of renewable resources, particularly food waste. The complexity of food waste by-products also impairs the economic assessment of such biorefineries. In any case, high value-added bio-based products deriving from food waste and agricultural by-products should be generated in large amounts, whereas the final market price should be competitive with the chemically produced counterparts [274].

The co-production of fuels and platform chemicals has been the main driver for the configuration of biorefinery scenarios. Biorefining of food waste implements bioprocesses like acidogenesis, fermentation, solventogenesis, oleaginous processes, etc., that yield several products like biofertilizers, animal feed, and biochemicals $[14,275]$. Nonetheless, bioenergy production is a constructive process for biomass; therefore, to maintain the sustainability, it is advocated that a wide range of bio-products are obtained, instead of a single line product. Several researchers have highlighted the importance of recycling agricultural and industrial wastes through biotransformation by applying a biorefinery concept, utilizing waste as the main feedstock [276].

As previously stated, cheese whey is found among the most significant (and unavoidable) industrial waste streams. Proper disposal and reuse strategies, through bioprocess integration, are unequivocal to mitigate the vast amounts of non-avoidable food waste. Currently, conventional treatments for cheese whey include landfill disposal or anaerobic digestion with focus on BOD and COD reduction, rather than the production of biochemicals, bioenergy, and other value-added novel products [277]. Thus, new approaches for refining have been applied to convert dairy by-products into several valuable bio-based products, such as feed additives, bioplastics, and biochemicals—but also generate high-volume yet lower-value products (bioethanol), or high-value but low-volume products, as nutraceuticals [278].

As it was reported in the previous sections, approaches for cheese whey valorization so far do not exploit the full potential, particularly with respect to food applications. From one point, the protein fraction of cheese whey has been employed to obtain WP to manufacture edible films and coatings, hydrogels, and nutraceuticals (bioactive peptides), among others. The enhanced nutritional value, along with the health benefits, that whey proteins confer [238] have established whey as a high-value raw material in the food industry, with emerging and novel applications. On the other hand, lactose is a precursor substrate for the fermentative synthesis of lactic acid, succinic acid, and polyhydroxyalkanoates, among others [14]. Lactose can be directly fermented by microorganisms, e.g., Lactobacillus casei, Lactobacillus acidophilus, Lactobacillus delbrueckii, Lactobacillus plantarum, and Lactobacillus rhamnosus [27,279-283]. For instance, lactic acid is an organic biodegradable acid, extensively used in the pharmaceutical, textile, and food industries, where it has been employed in polymerization reactions to produce polylactic acid as a biodegradable polymer. Moreover, lactose deriving from cheese whey can provide a nutrient feedstock for the fermentative production of polyhydroxyalkanoates [284], demonstrating specific physical and mechanical properties. 
Biorefining has been already applied for the bioconversion of lactose from cheese whey into several valuable bio-products [10,285-287]; still, the majority of previously reported studies do not implement the complete capacity of cheese whey for food-based formulations. However, within the concept of integrated and consolidated bioprocesses, all streams should be exploited to yield multiple end-products. Likewise, by-products from whey protein manufacture are whey permeate and, following the extraction of lactose, delactosed whey permeate. These dairy-processing side-streams lack effective disposal or further exploitation routes; thus, they can be implemented to formulate cost competitive bio-based products under the concept of sustainable bio-economy targeting "zero waste" $[288,289]$. Equally, another possible alternative would be to combine different side streams, deriving from separate food processing industries, to configure bioprocesses for multiple end-products.

For instance, a recent study reported the fermentative production of bacterial cellulose (BC) using side-streams of Corinthian currants finishing (CFS), with high antioxidants and sugar content, via the evaluation of nitrogen sources addition and cheese whey [290]. Response surface methodology was applied to evaluate the conditions for BC production for CFS/cheese whey mixtures, concluding that optimum results were achieved on $50.4 \%$ whey permeate and $1.7 \%$ yeast, at $\mathrm{pH} 6.36$. On top of that, texture analysis was also conducted, indicating that BC could be implemented to formulate foods with potential prebiotic effects, thereby enhancing the functionality of the end-product. Within the same concept, wine lees were combined with cheese whey to develop a biorefining process with microbial oil as the target product [291]. The principal element to initiate process design was the utilization of carbon source from cheese whey (lactose) and the nitrogen source from wine lees, to substitute conventional and expensive chemicals. Polyphenol-rich extracts and tartaric salts, along with crude enzymes via solid state fermentation, were obtained via the treatment of wine lees to yield a nutrient-rich fermentation feedstock. Whey protein concentrate (WPC) was generated after membrane filtration to recover lactose, and at the end of the fermentation process, yeast cell mass could be used as animal feed. The proposed process induced the production of several end-products that could find diversified applications based on market demand, particularly in food formulation (antioxidants, microbial oil, whey protein). It is also worth noting that all streams were exploited, leading to minimal waste generation and enhanced economic feasibility.

A dairy waste biorefinery considering the treatment of cheese whey and cattle manure was proposed and presented by Chandra et al. [28]. Briefly, manure was directed to anaerobic digestion to yield volatile fatty acids, biomethane, hydrogen and fertilizers, considering that biofuel production is often included during a biorefinery design. On the other hand, cheese whey was employed in a more complete valorization scheme to obtain various products. In line with this, lactose was either used for GOS synthesis or for the fermentative production of lactic acid. Alternatively, an enzymatic hydrolysis step for lactose was suggested, prior to alcoholic fermentation or anaerobic digestion, to formulate ethanol. The proposed bioprocess entailed increased viability and sustainability, suggesting also almost zero waste; however, it could be further developed to a configuration that would separately exploit whey protein and lactose into more targeted high value-added food applications, as will be discussed in the following section.

Within the concept of targeted and novel food applications, whey was employed to produce a novel dried cheese whey using thermally-dried L. casei ATCC 393 and L. delbrueckii ssp. bulgaricus ATCC 11842, which were immobilized on casein [292]. Sensory analysis was also performed, and the results clearly demonstrated a novel probiotic product with enhanced aroma, improved shelf life, and protection from pathogenic strains. Hence, to induce novel value-added compounds, it is vital to develop a cheese whey valorization process that is directed principally on products that can separately stand as functional foods or components that are used in food formulation with enhanced properties.

\section{Innovative Refining Processes of Cheese Whey and Future Perspectives in Food Applications}

Cheese whey is an abundant and low-cost renewable resource deriving from the cheese industry. Utilization of food-grade enzymes and microbial cells, or chemical modification, indicate economically 
viable approaches for the conversion of cheese whey to produce functional food products. The growing worldwide demand for added-value food products, exhibiting functional properties, is accompanied by an equally increasing market of the latter products to meet consumers' demands. Meanwhile, the transition to bio-economy era demands the sustainable production of these foods, thereby impeding the development of effective bioprocessing and integrated strategies.

The current article demonstrates state-of-the-art processes for cheese whey valorization, towards the manufacture of emerging food additives and products. The majority of the configured processes are focused either only in protein or lactose streams from cheese whey. Evidently, published studies on integrated biorefineries using cheese whey are inadequate with respect to the investigation of both lactose and protein streams to yield food-based compounds. In the era of circular economy, the implementation of several processing methods should be indispensably included within a consolidated cheese whey biorefinery to generate functional foods with improved properties (Figure 4). The following suggested examples relating to food applications indicate solid perspective of novel integrated biorefinery approaches for high value-added food production.

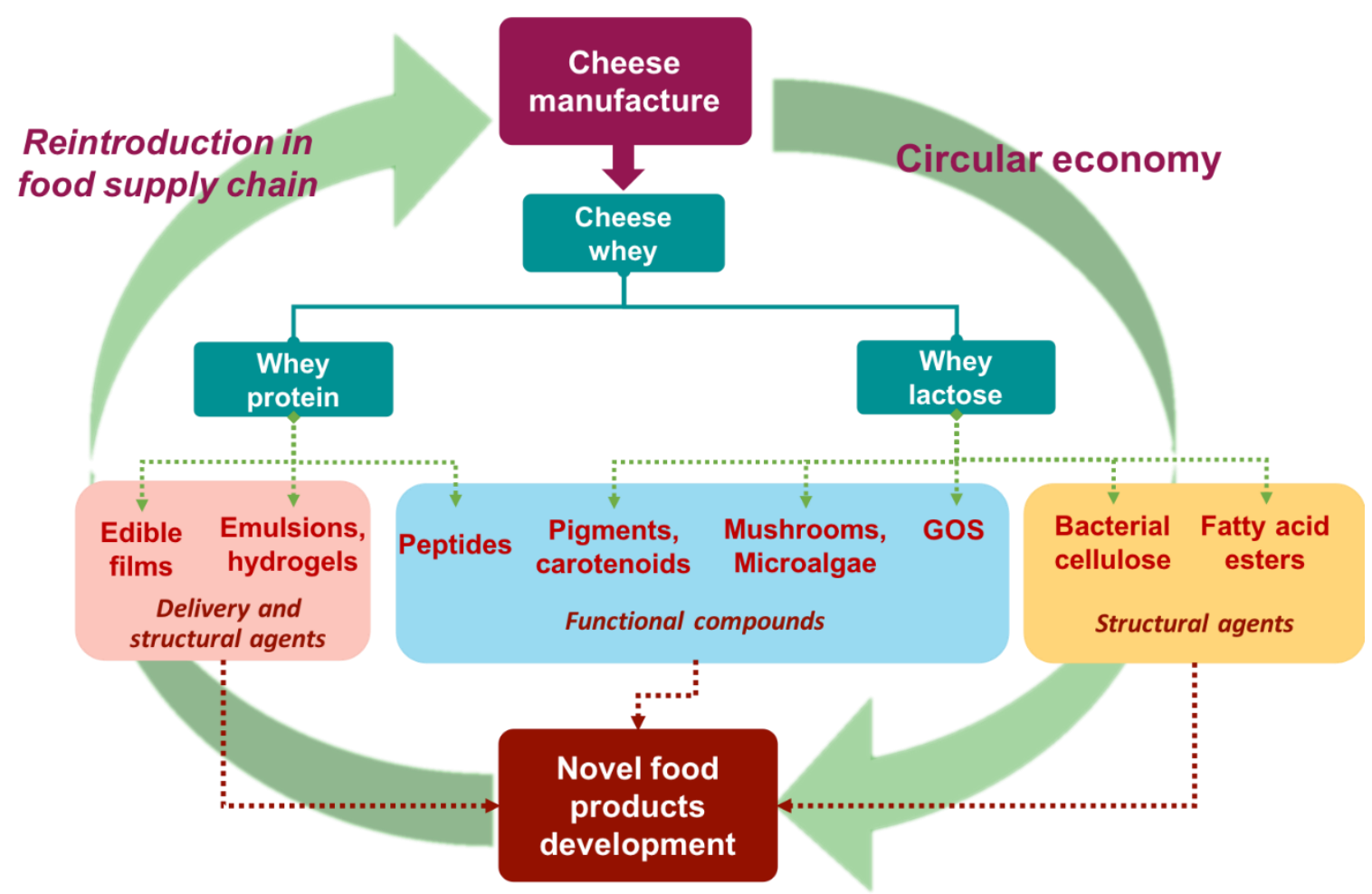

Figure 4. Proposed cheese whey-integrated biorefineries targeting food applications within the circular economy context.

An interesting paradigm to be potentially integrated for cheese whey valorization was introduced by Paximada et al. [293], where whey protein emulsions using bacterial cellulose were produced as an alternative to commercial thickeners, such as xanthan gum and locust bean gum [293]. Xanthan gum is considered an important food thickener, providing high shear-thinning behavior in food products [294]. Worth noting is that Paximada et al. [293] stated that bacterial cellulose had a better shear thinning profile than xanthan gum [293]. Results indicated that lower bacterial cellulose concentration was required compared to xanthan gum or locust bean gum to obtain emulsions with similar rheological properties, and also that bacterial cellulose produced from food by-products is a cheaper alternative to commercial gums [293]. The interaction between whey protein and bacterial cellulose was investigated by Peng et al. [295], noting that bacterial cellulose modified the properties of whey protein fibrillar 
gel [295]. Particularly, bacterial cellulose addition resulted in a bifibrillar gel, improving whey protein fibril alignment rather than the absence of bacterial cellulose [295].

In Section 2.2.3, we demonstrated that the fermentation of Spirulina in cheese whey is an unexploited bioprocess, regardless of the several attempts performed to incorporate the highly nutritious Spirulina in foods [134]. Particularly, Spirulina has been used as a healthy additive for novel ice cream production with high nutritional value [296]. The estimated cost of the final product was found to be cost competitive within the functional products segment [296]. The addition of Spirulina platensis in soft cheese significantly enriched the protein and carotenoid content of the final product [297]. Furthermore, the protein concentrate extracted from the biomass of Spirulina sp. has been utilized as functional coating material to encapsulate pigments of commercial interest, such as phycocyanin. Although Spirulina sp. is a rich source of this pigment, the production of ultrafine fibers by the electrospinning method resulted in increased thermal stability of phycocyanin [298]. Spirulina sp. and Chlorella sp. have also been employed for the production of many food products, such as gels $[299,300]$ and fermented milk [135]. In the production of functional fermented milk products, the co-addition of these microalgae and probiotics increased the viability of the probiotic bacteria [135]. Additionally, Terpou et al. [301] reported that whey protein hydrolysate and whey protein concentrate can also promote probiotic viability [301]. These studies indicate that the utilization of both whey protein products and microalgae, previously grown on whey lactose, could be employed for the development of probiotic products with enhanced beneficial value.

This article showed that several protein sources, including Spirulina and whey protein, could act as delivery agents for bioactive compounds, including pigments, carotenoids, or GOS, which are produced via microbial or enzymatic bioprocesses using lactose from whey. Additionally, compounds such as lactose esters and bacterial cellulose can be utilized as thickeners and emulsifiers, altering the rheological behavior of food $[66,293]$.

Therefore, to conform to the concept of circular economy that would ideally allow the reintroduction of produced bio-based food components in the food chain, there is a necessity to undertake novel approaches for biorefinery development, considering also the founding pillars of economy, society, and environment. In a complete cascading process, cheese whey would be initially treated to obtain the protein rich fraction and whey lactose. Whey protein fraction could be treated to result in the formulation of nutrient supplements, encapsulation agents of the fermentative production of Spirulina, and further inclusion in food. Equally, whey protein could be employed to encapsulate probiotic strains, to manufacture end-products with enhanced nutritional value and sensory characteristics. On the other hand, the lactose-rich stream could be efficiently valorized via enzymatic and microbial bioconversion processes. Synthesis of GOS, either with crude or commercial enzymes, confers a notable option, considering the prominent increase in the market of prebiotics. Purified GOS can be obtained via conventional methods (activated charcoal, membranes, etc.) or via the use of yeast strains (Kluyveromyces marxianus, Saccharomyces cerevisiae) that consume the unreacted lactose, glucose, and galactose. Appropriate selection of strains in the latter case could lead to additional value-added product formation, whereas the yeast cells after GOS recovery could serve as potential animal feed supplements. The suggested scenario resembles the dairy waste biorefinery proposed by Chandra et al. [28]; however, we elaborate more on high value-added products that will find end applications in the food industry rather than biofuels [28].

Within this concept, our research group at the Department of Food Science \& Technology of the Ionian University is currently focusing on the development of an integrated cheese whey biorefinery scheme. More specifically, lactose deriving from whey will be used for the production of potential probiotic starter cultures from non-dairy Lactobacillus strains and the production of bacterial cellulose. Subsequently, bacterial cellulose will be combined with whey protein to form immobilization support matrices for probiotic cultures that will be further incorporated in dairy products (e.g., cheese, yogurt). Overall, it is envisaged to configure a refining process to implement both lactose and protein streams, resulting in high value-added products that will be introduced in the food manufacturing sector 
(Figure 4). It is easily deduced from these studies that intensive and contemplated effort is conducted to establish an integral process to appraise a closed-loop food supply chain through the manufacture of novel food products. Ultimately, novel approaches will yield alternative bio-based components exhibiting enhanced physicochemical properties, sensory characteristics, and nutritional value.

Author Contributions: Conceptualization, N.K.; investigation, I.K.L., A.P., A.T., V.K., and N.K.; resources, I.K.L., A.P., A.T., and V.K.; writing-original draft preparation, I.K.L., A.P., A.T., V.K., and D.K.; writing-review and editing, A.P., V.K., E.E., and N.K.; supervision, E.E. and N.K.; project administration, N.K.

Funding: This study is part of the project "Valorization of cheese dairy wastes for the production of high added-value products" (MIS 5007020) which is implemented under the Action "Targeted Actions to Promote Research and Technology in Areas of Regional Specialization and New Competitive Areas in International Level", funded by the Operational Programme "Ionian Islands 2014-2020" and co-financed by Greece and the European Union (European Regional Development Fund).

Conflicts of Interest: The authors declare no conflict of interest.

\section{References}

1. Lievore, P.; Simões, D.R.S.; Silva, K.M.; Drunkler, N.L.; Barana, A.C.; Nogueira, A.; Demiate, I.M. Chemical characterisation and application of acid whey in fermented milk. J. Food Sci. Technol. 2015, 52, 2083-2092. [CrossRef] [PubMed]

2. Masotti, F.; Cattaneo, S.; Stuknytè, M.; De Noni, I. Technological tools to include whey proteins in cheese: Current status and perspectives. Trends Food Sci. Technol. 2017, 64, 102-114. [CrossRef]

3. Fernández-Gutiérrez, D.; Veillette, M.; Giroir-Fendler, A.; Ramirez, A.A.; Faucheux, N.; Heitz, M. Biovalorization of saccharides derived from industrial wastes such as whey: A review. Rev. Environ. Sci. BioTechnol. 2017, 16, 147-174. [CrossRef]

4. Carvalho, F.; Prazeres, A.R.; Rivas, J. Cheese whey wastewater: Characterization and treatment. Sci. Total Environ. 2013, 445-446, 385-396. [CrossRef] [PubMed]

5. Wang, Z.; Wang, Z.; Lin, S.; Jin, H.; Gao, S.; Zhu, Y.; Jin, J. Nanoparticle-templated nanofiltration membranes for ultrahigh performance desalination. Nat. Commun. 2018, 9, 2004. [CrossRef]

6. Yadav, J.S.S.; Yan, S.; Pilli, S.; Kumar, L.; Tyagi, R.D.; Surampalli, R.Y. Cheese whey: A potential resource to transform into bioprotein, functional/nutritional proteins and bioactive peptides. Biotechnol. Adv. 2015, 33, 756-774. [CrossRef] [PubMed]

7. Chatzipaschali, A.A.; Stamatis, A.G. Biotechnological Utilization with a Focus on Anaerobic Treatment of Cheese Whey: Current Status and Prospects. Energies 2012, 5, 3492-3525. [CrossRef]

8. Domingos, J.M.B.; Puccio, S.; Martinez, G.A.; Amaral, N.; Reis, M.A.M.; Bandini, S.; Fava, F.; Bertin, L. Cheese whey integrated valorisation: Production, concentration and exploitation of carboxylic acids for the production of polyhydroxyalkanoates by a fed-batch culture. Chem. Eng. J. 2018, 336, 47-53. [CrossRef]

9. Valta, K.; Damala, P.; Angeli, E.; Antonopoulou, G.; Malamis, D.; Haralambous, K.J. Current Treatment Technologies of Cheese Whey and Wastewater by Greek Cheese Manufacturing Units and Potential Valorisation Opportunities. Waste Biomass Valorization 2017, 8, 1649-1663. [CrossRef]

10. Remón, J.; Ruiz, J.; Oliva, M.; García, L.; Arauzo, J. Cheese whey valorisation: Production of valuable gaseous and liquid chemicals from lactose by aqueous phase reforming. Energy Convers. Manag. 2016, 124, 453-469. [CrossRef]

11. Vasala, A.; Panula, J.; Neubauer, P. Efficient lactic acid production from high salt containing dairy by-products by Lactobacillus salivarius ssp. salicinius with pre-treatment by proteolytic microorganisms. J. Biotechnol. 2005, 117, 421-431. [CrossRef] [PubMed]

12. Prazeres, A.R.; Carvalho, F.; Rivas, J. Cheese whey management: A review. J. Environ. Manag. 2012, 110, 48-68. [CrossRef] [PubMed]

13. Banaszewska, A.; Cruijssen, F.; Claassen, G.D.H.; van der Vorst, J.G.A.J. Effect and key factors of byproducts valorization: The case of dairy industry. J. Dairy Sci. 2014, 97, 1893-1908. [CrossRef] [PubMed]

14. Koutinas, A.A.; Vlysidis, A.; Pleissner, D.; Kopsahelis, N.; Lopez Garcia, I.; Kookos, I.K.; Papanikolaou, S.; Kwan, T.H.; Lin, C.S.K. Valorization of industrial waste and by-product streams via fermentation for the production of chemicals and biopolymers. Chem. Soc. Rev. 2014, 43, 2587-2627. [CrossRef] [PubMed] 
15. Panghal, A.; Patidar, R.; Jaglan, S.; Chhikara, N.; Khatkar, S.K.; Gat, Y.; Sindhu, N. Whey valorization: Current options and future scenario-A critical review. Nutr. Food Sci. 2018, 48, 520-535. [CrossRef]

16. Corrochano, A.R.; Buckin, V.; Kelly, P.M.; Giblin, L. Invited review: Whey proteins as antioxidants and promoters of cellular antioxidant pathways. J. Dairy Sci. 2018, 101, 4747-4761. [CrossRef] [PubMed]

17. Królczyk, J.B.; Dawidziuk, T.; Janiszewska-Turak, E.; Sołowiej, B. Use of Whey and Whey Preparations in the Food Industry-A Review. Pol. J. Food Nutr. Sci. 2016, 66, 157. [CrossRef]

18. Terpou, A.; Bosnea, L.; Kanellaki, M. Effect of Mastic Gum (Pistacia Lentiscus Via Chia) as a Probiotic Cell Encapsulation Carrier for Functional Whey Beverage Production. SCIOL Biomed. 2017, 1, 1-10.

19. Skryplonek, K.; Dmytrów, I.; Mituniewicz-Małek, A. Probiotic fermented beverages based on acid whey. J. Dairy Sci. 2019, 102, 7773-7780. [CrossRef] [PubMed]

20. Das, M.; Raychaudhuri, A.; Ghosh, S.K. Supply Chain of Bioethanol Production from Whey: A Review. Procedia Environ. Sci. 2016, 35, 833-846. [CrossRef]

21. Dedenaro, G.; Costa, S.; Rugiero, I.; Pedrini, P.; Tamburini, E. Valorization of Agri-Food Waste via Fermentation: Production of 1-lactic Acid as a Building Block for the Synthesis of Biopolymers. Appl. Sci. 2016, 6, 379. [CrossRef]

22. Ganju, S.; Gogate, P.R. A review on approaches for efficient recovery of whey proteins from dairy industry effluents. J. Food Eng. 2017, 215, 84-96. [CrossRef]

23. Uduwerella, G.; Chandrapala, J.; Vasiljevic, T. Preconcentration of yoghurt base by ultrafiltration for reduction in acid whey generation during Greek yoghurt manufacturing. Int. J. Dairy Technol. 2018, 71, 71-80. [CrossRef]

24. Marx, M.; Kulozik, U. Thermal denaturation kinetics of whey proteins in reverse osmosis and nanofiltration sweet whey concentrates. Int. Dairy J. 2018, 85, 270-279. [CrossRef]

25. Mawson, A.J. Bioconversions for whey utilization and waste abatement. Bioresour. Technol. 1994, 47, 195-203. [CrossRef]

26. Pescuma, M.; de Valdez, G.F.; Mozzi, F. Whey-derived valuable products obtained by microbial fermentation. Appl. Microbiol. Biotechnol. 2015, 99, 6183-6196. [CrossRef] [PubMed]

27. Terpou, A.; Gialleli, A.-I.; Bekatorou, A.; Dimitrellou, D.; Ganatsios, V.; Barouni, E.; Koutinas, A.A.; Kanellaki, M. Sour milk production by wheat bran supported probiotic biocatalyst as starter culture. Food Bioprod. Process. 2017, 101, 184-192. [CrossRef]

28. Chandra, R.; Castillo-Zacarias, C.; Delgado, P.; Parra-Saldívar, R. A biorefinery approach for dairy wastewater treatment and product recovery towards establishing a biorefinery complexity index. J. Clean. Prod. 2018, 183, 1184-1196. [CrossRef]

29. Villamiel, M.; Montilla, A.; Olano, A.; Corzo, N. Production and Bioactivity of Oligosaccharides Derived from Lactose. In Food Oligosaccharides: Production, Analysis and Bioactivity; John Wiley \& Sons, Ltd.: Chichester, UK, 2014; pp. 135-167.

30. Nooshkam, M.; Babazadeh, A.; Jooyandeh, H. Lactulose: Properties, techno-functional food applications, and food grade delivery system. Trends Food Sci. Technol. 2018, 80, 23-34. [CrossRef]

31. Gibson, G.R.; Roberfroid, M.B. Dietary modulation of the human colonic microbiota: Introducing the concept of prebiotics. J. Nutr. 1995, 125, 1401-1412. [CrossRef]

32. Gibson, G.R.; Hutkins, R.; Sanders, M.E.; Prescott, S.L.; Reimer, R.A.; Salminen, S.J.; Scott, K.; Stanton, C.; Swanson, K.S.; Cani, P.D.; et al. Expert consensus document: The International Scientific Association for Probiotics and Prebiotics (ISAPP) consensus statement on the definition and scope of prebiotics. Nat. Rev. Gastroenterol. Hepatol. 2017, 14, 491-502. [CrossRef] [PubMed]

33. Loveren, H.v.; Sanz, Y.; Salminen, S. Health Claims in Europe: Probiotics and Prebiotics as Case Examples. Annu. Rev. Food Sci. Technol. 2012, 3, 247-261. [CrossRef] [PubMed]

34. Moreno, F.J.; Corzo, N.; Montilla, A.; Villamiel, M.; Olano, A. Current state and latest advances in the concept, production and functionality of prebiotic oligosaccharides. Curr. Opin. Food Sci. 2017, 13, 50-55. [CrossRef]

35. Sangwan, V.; Tomar, S.K.; Ali, B.; Singh, R.R.B.; Singh, A.K. Production of $\beta$-galactosidase from Streptococcus thermophilus for galactooligosaccharides synthesis. J. Food Sci. Technol. 2015, 52, 4206-4215. [CrossRef] [PubMed]

36. Hernández, O.; Ruiz-Matute, A.I.; Olano, A.; Moreno, F.J.; Sanz, M.L. Comparison of fractionation techniques to obtain prebiotic galactooligosaccharides. Int. Dairy J. 2009, 19, 531-536. [CrossRef] 
37. Rastall, R.A. Functional oligosaccharides: Application and manufacture. Annu. Rev. Food Sci. Technol. 2010, 1, 305-339. [CrossRef] [PubMed]

38. Rastall, R.A. Galacto-Oligosaccharides as Prebiotic Food Ingredients. In Prebiotics: Development E Application; John Wiley \& Sons, Ltd.: Hoboken, NJ, USA, 2012; pp. 101-109.

39. Adroit market research. Available online: https://www.adroitmarketresearch.com/industry-reports/galactooligosaccharides-gos-market (accessed on 15 June 2019).

40. Anadón, A.; Martínez-Larrañaga, M.R.; Arés, I.; Martínez, M.A. Chapter 1-Prebiotics and Probiotics: An Assessment of Their Safety and Health Benefits. In Probiotics, Prebiotics, and Synbiotics; Watson, R.R., Preedy, V.R., Eds.; Academic Press: Cambridge, MA, USA, 2016; pp. 3-23.

41. Torres, D.P.M.; Gonçalves, M.d.P.F.; Teixeira, J.A.; Rodrigues, L.R. Galacto-Oligosaccharides: Production, Properties, Applications, and Significance as Prebiotics. Compr. Rev. Food Sci. Food Saf. 2010, 9, 438-454. [CrossRef]

42. Martins, G.N.; Ureta, M.M.; Tymczyszyn, E.E.; Castilho, P.C.; Gomez-Zavaglia, A. Technological Aspects of the Production of Fructo and Galacto-Oligosaccharides. Enzymatic Synthesis and Hydrolysis. Front. Nutr. 2019, 6, 78. [CrossRef] [PubMed]

43. Aït-Aissa, A.; Aïder, M. Lactulose: Production and use in functional food, medical and pharmaceutical applications. Practical and critical review. Int. J. Food Sci. Technol. 2014, 49, 1245-1253. [CrossRef]

44. Contesini, F.J.; de Lima, E.A.; Mandelli, F.; Borin, G.P.; Alves, R.F.; Terrasan, C.R.F. Carbohydrate Active Enzymes Applied in the Production of Functional Oligosaccharides. In Encyclopedia of Food Chemistry; Melton, L., Shahidi, F., Varelis, P., Eds.; Academic Press: Oxford, UK, 2019; pp. 30-34.

45. Albayrak, N.; Yang, S.T. Production of galacto-oligosaccharides from lactose by Aspergillus oryzae beta-galactosidase immobilized on cotton cloth. Biotechnol. Bioeng. 2002, 77, 8-19. [CrossRef]

46. Guerrero, C.; Vera, C.; Acevedo, F.; Illanes, A. Simultaneous synthesis of mixtures of lactulose and galacto-oligosaccharides and their selective fermentation. J. Biotechnol. 2015, 209, 31-40. [CrossRef] [PubMed]

47. Wichienchot, S.; Ishak, W.R.B.W. Prebiotics and Dietary Fibers from Food Processing By-Products. In Food Processing By-Products and Their Utilization; John Wiley \& Sons Ltd.: Hoboken, NJ, USA, 2017; pp. 137-174.

48. Splechtna, B.; Nguyen, T.-H.; Zehetner, R.; Lettner, H.P.; Lorenz, W.; Haltrich, D. Process development for the production of prebiotic galacto-oligosaccharides from lactose using $\beta$-galactosidase from Lactobacillus $\mathrm{sp}$. Biotechnol. J. 2007, 2, 480-485. [CrossRef] [PubMed]

49. Das, R.; Sen, D.; Sarkar, A.; Bhattacharyya, S.; Bhattacharjee, C. A Comparative Study on the Production of Galacto-oligosaccharide from Whey Permeate in Recycle Membrane Reactor and in Enzymatic Batch Reactor. Ind. Eng. Chem. Res. 2011, 50, 806-816. [CrossRef]

50. Díez-Municio, M.; Montilla, A.; Jimeno, M.L.; Corzo, N.; Olano, A.; Moreno, F.J. Synthesis and Characterization of a Potential Prebiotic Trisaccharide from Cheese Whey Permeate and Sucrose by Leuconostoc mesenteroides Dextransucrase. J. Agric. Food Chem. 2012, 60, 1945-1953. [CrossRef] [PubMed]

51. Corzo-Martinez, M.; Luscher, A.; de Las Rivas, B.; Muñoz, R.; Moreno, F.J. Valorization of Cheese and Tofu Whey through Enzymatic Synthesis of Lactosucrose. PLoS ONE 2015, 10, e0139035. [CrossRef] [PubMed]

52. Foda, M.I.; Lopez-Leiva, M. Continuous production of oligosaccharides from whey using a membrane reactor. Process Biochem. 2000, 35, 581-587. [CrossRef]

53. Fischer, C.; Kleinschmidt, T. Synthesis of galactooligosaccharides using sweet and acid whey as a substrate. Int. Dairy J. 2015, 48, 15-22. [CrossRef]

54. Geiger, B.; Nguyen, H.-M.; Wenig, S.; Nguyen, H.A.; Lorenz, C.; Kittl, R.; Mathiesen, G.; Eijsink, V.G.H.; Haltrich, D.; Nguyen, T.-H. From by-product to valuable components: Efficient enzymatic conversion of lactose in whey using $\beta$-galactosidase from Streptococcus thermophilus. BioChem. Eng. J. 2016, 116, 45-53. [CrossRef]

55. Scott, F.; Vera, C.; Conejeros, R. Chapter 7-Technical and Economic Analysis of Industrial Production of Lactose-Derived Prebiotics with Focus on Galacto-Oligosaccharides. In Lactose-Derived Prebiotics; Illanes, A., Guerrero, C., Vera, C., Wilson, L., Conejeros, R., Scott, F., Eds.; Academic Press: San Diego, CA, USA, 2016; pp. 261-284.

56. Market Research. Available online: https://www.marketresearch.com/MarketsandMarkets-v3719/SucroseEsters-Application-Food-Detergents-9762838/ (accessed on 15 June 2019). 
57. Staroń, J.; Dabrowski, J.M.; Cichoń, E.; Guzik, M. Lactose esters: Synthesis and biotechnological applications. Crit. Rev. Biotechnol. 2018, 38, 245-258. [CrossRef]

58. Papadaki, A.; Cipolatti, E.P.; Aguieiras, E.C.G.; Cerqueira Pinto, M.C.; Kopsahelis, N.; Freire, D.M.G.; Mandala, I.; Koutinas, A.A. Development of Microbial Oil Wax-Based Oleogel with Potential Application in Food Formulations. Food Bioprocess Technol. 2019, 12, 899-909. [CrossRef]

59. Papadaki, A.; Fernandes, K.V.; Chatzifragkou, A.; Aguieiras, E.C.G.; da Silva, J.A.C.; Fernandez-Lafuente, R.; Papanikolaou, S.; Koutinas, A.; Freire, D.M.G. Bioprocess development for biolubricant production using microbial oil derived via fermentation from confectionery industry wastes. Bioresour. Technol. 2018, 267, 311-318. [CrossRef] [PubMed]

60. Papadaki, A.; Mallouchos, A.; Efthymiou, M.-N.; Gardeli, C.; Kopsahelis, N.; Aguieiras, E.C.G.; Freire, D.M.G.; Papanikolaou, S.; Koutinas, A.A. Production of wax esters via microbial oil synthesis from food industry waste and by-product streams. Bioresour. Technol. 2017, 245, 274-282. [CrossRef] [PubMed]

61. Fernandes, K.V.; Papadaki, A.; da Silva, J.A.C.; Fernandez-Lafuente, R.; Koutinas, A.A.; Freire, D.M.G. Enzymatic esterification of palm fatty-acid distillate for the production of polyol esters with biolubricant properties. Ind. Crop. Prod. 2018, 116, 90-96. [CrossRef]

62. Scholnick, F.; Sucharski, M.K.; Linfield, W.M. Lactose-derived surfactants (I) fatty esters of lactose. J. Am. Oil Chem. Soc. 1974, 51, 8-11. [CrossRef]

63. Lay, L.; Panza, L.; Riva, S.; Khitri, M.; Tirendi, S. Regioselective acylation of disaccharides by enzymatic transesterification. Carbohydr. Res. 1996, 291, 197-204. [CrossRef]

64. Riva, S.; Chopineau, J.; Kieboom, A.P.G.; Klibanov, A.M. Protease-catalyzed regioselective esterification of sugars and related compounds in anhydrous dimethylformamide. J. Am. Chem. Soc. 1988, 110, 584-589. [CrossRef]

65. Enayati, M.; Gong, Y.; Goddard, J.M.; Abbaspourrad, A. Synthesis and characterization of lactose fatty acid ester biosurfactants using free and immobilized lipases in organic solvents. Food Chem. 2018, 266, 508-513. [CrossRef]

66. Lee, S.-M.; Wagh, A.; Sandhu, G.; Walsh, M.K. Emulsification Properties of Lactose Fatty Acid Esters. Food Nutr. Sci. 2018, 09, 17. [CrossRef]

67. Ambati, R.R.; Phang, S.M.; Ravi, S.; Aswathanarayana, R.G. Astaxanthin: Sources, extraction, stability, biological activities and its commercial applications-A review. Mar. Drugs 2014, 12, 128-152. [CrossRef]

68. Tanumihardjo, S.A. Carotenoids: Health Effects. In Encyclopedia of Human Nutrition, 3rd ed.; Caballero, B., Ed.; Academic Press: Waltham, MA, USA, 2013; pp. 292-297.

69. Eggersdorfer, M.; Wyss, A. Carotenoids in human nutrition and health. Arch. Biochem. Biophys. 2018, 652, 18-26. [CrossRef]

70. Bogacz-Radomska, L.; Harasym, J. $\beta$-Carotene-Properties and production methods. Food Qual. Saf. 2018, 2, 69-74. [CrossRef]

71. Mata-Gómez, L.C.; Montañez, J.C.; Méndez-Zavala, A.; Aguilar, C.N. Biotechnological production of carotenoids by yeasts: An overview. Microb. Cell Fact. 2014, 13, 12. [CrossRef] [PubMed]

72. Shah, M.M.R.; Liang, Y.; Cheng, J.J.; Daroch, M. Astaxanthin-Producing Green Microalga Haematococcus pluvialis: From Single Cell to High Value Commercial Products. Front. Plant Sci. 2016, 7, 531. [CrossRef] [PubMed]

73. Yuan, J.P.; Peng, J.; Yin, K.; Wang, J.H. Potential health-promoting effects of astaxanthin: A high-value carotenoid mostly from microalgae. Mol. Nutr. Food Res. 2011, 55, 150-165. [CrossRef] [PubMed]

74. Villegas-Méndez, M.Á.; Aguilar-Machado, D.E.; Balagurusamy, N.; Montañez, J.; Morales-Oyervides, L. Agro-industrial wastes for the synthesis of carotenoids by Xanthophyllomyces dendrorhous: Mesquite pods-based medium design and optimization. BioChem. Eng. J. 2019, 150, 107260. [CrossRef]

75. Barredo, J.L.; García-Estrada, C.; Kosalkova, K.; Barreiro, C. Biosynthesis of Astaxanthin as a Main Carotenoid in the Heterobasidiomycetous Yeast Xanthophyllomyces dendrorhous. J. Fungi 2017, 3, 44. [CrossRef]

76. Roukas, T.; Varzakakou, M.; Kotzekidou, P. From Cheese Whey to Carotenes by Blakeslea trispora in a Bubble Column Reactor. Appl. Biochem. Biotechnol. 2015, 175, 182-193. [CrossRef] [PubMed]

77. Khodaiyan, F.; Razavi, S.H.; Mousavi, S.M. Optimization of canthaxanthin production by Dietzia natronolimnaea HS-1 from cheese whey using statistical experimental methods. BioChem. Eng. J. 2008, 40, 415-422. [CrossRef] 
78. Liu, Z.-Q.; Zhang, J.-F.; Zheng, Y.-G.; Shen, Y.-C. Improvement of astaxanthin production by a newly isolated Phaffia rhodozyma mutant with low-energy ion beam implantation. J. Appl. Microbiol. 2008, 104, 861-872. [CrossRef]

79. Sun, N.; Wang, Y.; Li, Y.-T.; Huang, J.-C.; Chen, F. Sugar-based growth, astaxanthin accumulation and carotenogenic transcription of heterotrophic Chlorella zofingiensis (Chlorophyta). Process Biochem. 2008, 43, 1288-1292. [CrossRef]

80. Aksu, Z.; Eren, A.T. Carotenoids production by the yeast Rhodotorula mucilaginosa: Use of agricultural wastes as a carbon source. Process Biochem. 2005, 40, 2985-2991. [CrossRef]

81. Mantzouridou, F.; Tsimidou, M.Z.; Roukas, T. Performance of Crude Olive Pomace Oil and Soybean Oil during Carotenoid Production by Blakeslea trispora in Submerged Fermentation. J. Agric. Food Chem. 2006, 54, 2575-2581. [CrossRef] [PubMed]

82. Varzakakou, M.; Roukas, T. Identification of carotenoids produced from cheese whey by Blakeslea trispora in submerged fermentation. Prep. Biochem. Biotechnol. 2009, 40, 76-82. [CrossRef] [PubMed]

83. Varzakakou, M.; Roukas, T.; Kotzekidou, P. Effect of the ratio of (+) and (-) mating type of Blakeslea trispora on carotene production from cheese whey in submerged fermentation. World J. Microbiol. Biotechnol. 2010, 26, 2151-2156. [CrossRef]

84. Roukas, T.; Mantzouridou, F.; Boumpa, T.; Vafiadou, A.; Goksungur, Y. Production of $\beta$-Carotene from Beet Molasses and Deproteinized Whey by Blakeslea trispora. Food Biotechnol. 2007, 17, 203-215. [CrossRef]

85. Psani, M.; Roukas, T.; Kotzekidou, P. Evaluation of cheese whey as substrate for carotenoids production by Blakeslea trispora. Australian J. Dairy Technol. 2006, 61, 222.

86. Azmi, W.; Thakur, M.; Kumar, A. Production of beta-carotene from deproteinized waste whey filtrate using Mucor azygosporus MTCC 414 in submerged fermentation. Acta Microbiol. Immunol. Hung. 2011, 58, 189-200. [CrossRef] [PubMed]

87. Marova, I.; Carnecka, M.; Halienova, A.; Certik, M.; Dvorakova, T.; Haronikova, A. Use of several waste substrates for carotenoid-rich yeast biomass production. J. Environ. Manag. 2012, 95, S338-S342. [CrossRef]

88. Frengova, G.; Simova, E.; Beshkova, D. Use of whey ultrafiltrate as a substrate for production of carotenoids by the yeast Rhodotorula rubra. Appl. Biochem. Biotechnol. 2004, 112, 133-141. [CrossRef]

89. Frengova, G.; Simova, E.; Pavlova, K.; Beshkova, D.; Grigorova, D. Formation of carotenoids by Rhodotorula glutinis in whey ultrafiltrate. Biotechnol. Bioeng. 1994, 44, 888-894. [CrossRef]

90. Simova, E.D.; Frengova, G.I.; Beshkova, D.M. Synthesis of carotenoids by Rhodotorula rubra GED8 co-cultured with yogurt starter cultures in whey ultrafiltrate. J. Ind. Microbiol. Biotechnol. 2004, 31, 115-121. [CrossRef] [PubMed]

91. Valduga, E.; Tatsch, P.; Vanzo, L.T.; Rauber, F.; Di Luccio, M.; Treichel, H. Assessment of hydrolysis of cheese whey and use of hydrolysate for bioproduction of carotenoids by Sporidiobolus salmonicolor CBS 2636. J. Sci. Food Agric. 2009, 89, 1060-1065. [CrossRef]

92. Li, X.; Wang, D.; Cai, D.; Zhan, Y.; Wang, Q.; Chen, S. Identification and High-level Production of Pulcherrimin in Bacillus licheniformis DW2. Appl. Biochem. Biotechnol. 2017, 183, 1323-1335. [CrossRef] [PubMed]

93. Turkel, S.; Korukluoglu, M.; Yavuz, M. Biocontrol Activity of the Local Strain of Metschnikowia pulcherrima on Different Postharvest Pathogens. Biotechnol. Res. Int. 2014, 2014, 397167. [CrossRef]

94. Türkel, S.; Ener, B. Isolation and Characterization of New Metschnikowia pulcherrima Strains as Producers of the Antimicrobial Pigment Pulcherrimin. Z. Naturforsch. C 2009, 64, 405-410. [CrossRef]

95. Savini, V.; Hendrickx, M.; Sisti, M.; Masciarelli, G.; Favaro, M.; Fontana, C.; Pitzurra, L.; Arzeni, D.; Astolfi, D.; Catavitello, C.; et al. An atypical, pigment-producing Metschnikowia strain from a leukaemia patient. Med. Mycol. 2013, 51, 438-443. [CrossRef] [PubMed]

96. Chreptowicz, K.; Sternicka, M.K.; Kowalska, P.D.; Mierzejewska, J. Screening of yeasts for the production of 2-phenylethanol (rose aroma) in organic waste-based media. Lett. Appl. Microbiol. 2018, 66, 153-160. [CrossRef]

97. Chantasuban, T.; Santomauro, F.; Gore-Lloyd, D.; Parsons, S.; Henk, D.; Scott, R.J.; Chuck, C. Elevated production of the aromatic fragrance molecule, 2-phenylethanol, using Metschnikowia pulcherrima through both de novo and ex novo conversion in batch and continuous modes. J. Chem. Technol. Biotechnol. 2018, 93, 2118-2130. [CrossRef]

98. Izawa, N.; Kudo, M.; Nakamura, Y.; Mizukoshi, H.; Kitada, T.; Sone, T. Production of aroma compounds from whey using Wickerhamomyces pijperi. AMB Express 2015, 5, 23. [CrossRef] 
99. Azeredo, H.M.C.; Barud, H.; Farinas, C.S.; Vasconcellos, V.M.; Claro, A.M. Bacterial Cellulose as a Raw Material for Food and Food Packaging Applications. Front. Sustain. Food Syst. 2019, 3. [CrossRef]

100. Tsouko, E.; Kourmentza, C.; Ladakis, D.; Kopsahelis, N.; Mandala, I.; Papanikolaou, S.; Paloukis, F.; Alves, V.; Koutinas, A. Bacterial Cellulose Production from Industrial Waste and by-Product Streams. Int. J. Mol. Sci. 2015, 16, 14832-14849. [CrossRef] [PubMed]

101. Andritsou, V.; de Melo, E.M.; Tsouko, E.; Ladakis, D.; Maragkoudaki, S.; Koutinas, A.A.; Matharu, A.S. Synthesis and Characterization of Bacterial Cellulose from Citrus-Based Sustainable Resources. ACS Omega 2018, 3, 10365-10373. [CrossRef]

102. Cacicedo, M.L.; Castro, M.C.; Servetas, I.; Bosnea, L.; Boura, K.; Tsafrakidou, P.; Dima, A.; Terpou, A.; Koutinas, A.; Castro, G.R. Progress in bacterial cellulose matrices for biotechnological applications. Bioresour. Technol. 2016, 213, 172-180. [CrossRef] [PubMed]

103. Vazquez, A.; Foresti, M.L.; Cerrutti, P.; Galvagno, M. Bacterial Cellulose from Simple and Low Cost Production Media by Gluconacetobacter xylinus. J. Polym. Environ. 2013, 21, 545-554. [CrossRef]

104. Tsouko, E.; Papadaki, A.; Papapostolou, H.; Ladakis, D.; Natsia, A.; Koutinas, A.; Kampioti, A.; Eriotou, E.; Kopsahelis, N. Valorization of Zante currant side-streams for the production of phenolic-rich extract and bacterial cellulose: A novel biorefinery concept. J. Chem. Technol. Biotechnol. 2019. [CrossRef]

105. Lee, K.-Y.; Buldum, G.; Mantalaris, A.; Bismarck, A. More Than Meets the Eye in Bacterial Cellulose: Biosynthesis, Bioprocessing, and Applications in Advanced Fiber Composites. Macromol. Biosci. 2014, 14, 10-32. [CrossRef] [PubMed]

106. Dahman, Y.; Jayasuriya, K.E.; Kalis, M. Potential of Biocellulose Nanofibers Production from Agricultural Renewable Resources: Preliminary Study. Appl. Biochem. Biotechnol. 2010, 162, 1647-1659. [CrossRef]

107. Son, H.-J.; Kim, H.-G.; Kim, K.-K.; Kim, H.-S.; Kim, Y.-G.; Lee, S.-J. Increased production of bacterial cellulose by Acetobacter sp. V6 in synthetic media under shaking culture conditions. Bioresour. Technol. 2003, 86, 215-219. [CrossRef]

108. Mikkelsen, D.; Flanagan, B.M.; Dykes, G.A.; Gidley, M.J. Influence of different carbon sources on bacterial cellulose production by Gluconacetobacter xylinus strain ATCC 53524. J. Appl. Microbiol. 2009, 107, 576-583. [CrossRef]

109. Thompson, D.N.; Hamilton, M.A. Production of bacterial cellulose from alternate feedstocks. Appl. Biochem. Biotechnol. 2001, 91, 503. [CrossRef]

110. Carreira, P.; Mendes, J.A.S.; Trovatti, E.; Serafim, L.S.; Freire, C.S.R.; Silvestre, A.J.D.; Neto, C.P. Utilization of residues from agro-forest industries in the production of high value bacterial cellulose. Bioresour. Technol. 2011, 102, 7354-7360. [CrossRef] [PubMed]

111. Battad-Bernardo, E.; McCrindle, S.L.; Couperwhite, I.; Neilan, B.A. Insertion of an E. coli lacZ gene in Acetobacter xylinus for the production of cellulose in whey. FEMS Microbiol. Lett. 2004, 231, 253-260. [CrossRef]

112. Salari, M.; Sowti Khiabani, M.; Rezaei Mokarram, R.; Ghanbarzadeh, B.; Samadi Kafil, H. Preparation and characterization of cellulose nanocrystals from bacterial cellulose produced in sugar beet molasses and cheese whey media. Int. J. Biol. Macromol. 2019, 122, 280-288. [CrossRef] [PubMed]

113. Revin, V.; Liyaskina, E.; Nazarkina, M.; Bogatyreva, A.; Shchankin, M. Cost-effective production of bacterial cellulose using acidic food industry by-products. Braz. J. Microbiol. 2018, 49, 151-159. [CrossRef] [PubMed]

114. Kothari, D.; Patel, S.; Kim, S.-K. Anticancer and other therapeutic relevance of mushroom polysaccharides: A holistic appraisal. Biomed. Pharmacother. 2018, 105, 377-394. [CrossRef]

115. Borthakur, M.; Joshi, S.R. Chapter 1-Wild Mushrooms as Functional Foods: The Significance of Inherent Perilous Metabolites. In New and Future Developments in Microbial Biotechnology Bioengineering; Gupta, V.K., Pandey, A., Eds.; Elsevier: Amsterdam, The Netherlands, 2019; pp. 1-12.

116. Diamantopoulou, P.; Papanikolaou, S.; Kapoti, M.; Komaitis, M.; Aggelis, G.; Philippoussis, A. Mushroom Polysaccharides and Lipids Synthesized in Liquid Agitated and Static Cultures. Part I: Screening Various Mushroom Species. Appl. Biochem. Biotechnol. 2012, 167, 536-551. [CrossRef]

117. Hereher, F.; ElFallal, A.; Toson, E.; Abou-Dobara, M.; Abdelaziz, M. Pilot study: Tumor suppressive effect of crude polysaccharide substances extracted from some selected mushroom. Beni-Suef Univ. J. Basic Appl. Sci. 2018, 7, 767-775. [CrossRef]

118. Giavasis, I. Polysaccharides from Medicinal Mushrooms for Potential Use as Nutraceuticals. In Polysaccharides Natural Fibers in Food and Nutrition; Benkeblia, N., Ed.; CRC Press: Boca Raton, FL, USA, 2014. 
119. Velez, M.E.V.; da Luz, J.M.R.; da Silva, M.d.C.S.; Cardoso, W.S.; Lopes, L.d.S.; Vieira, N.A.; Kasuya, M.C.M. Production of bioactive compounds by the mycelial growth of Pleurotus djamor in whey powder enriched with selenium. LWT 2019, 114, 108376. [CrossRef]

120. Mukhopadhyay, R.; Guha, A.K. A comprehensive analysis of the nutritional quality of edible mushroom Pleurotus sajor-caju grown in deproteinized whey medium. LWT Food Sci. Technol. 2015, 61, 339-345. [CrossRef]

121. Wu, X.J. Proximate Composition of Pleurotus ostreatus Grown in Whey Permeate Based Medium. Trans. ASABE 2009, 52, 1249-1254.

122. Bhak, G.; Song, M.; Lee, S.; Hwang, S. Response Surface Analysis of Solid State Growth of Pleurotus ostreatus Mycelia utilizing Whey Permeate. Biotechnol. Lett. 2005, 27, 1537-1541. [CrossRef] [PubMed]

123. Israilides, C.; Philippoussis, A. Bio-technologies of Recycling Agro-industrial Wastes for the Production of Commercially Important Fungal Polysaccharides and Mushrooms. Biotechnol. Genet. Eng. Rev. 2003, 20, 247-260. [CrossRef] [PubMed]

124. Wu, X.J.; Hansen, C. Effects of Whey Permeate-Based Medium on the Proximate Composition of Lentinus edodes in the Submerged Culture. J. Food Sci. 2006, 71, M174-M179. [CrossRef]

125. Wu, X.J.; Hansen, C. Antioxidant Capacity, Phenolic Content, and Polysaccharide Content of Lentinus edodes Grown in Whey Permeate-Based Submerged Culture. J. Food Sci. 2008, 73, M1-M8. [CrossRef] [PubMed]

126. Inglet, B.S.; Song, M.; Hansen, C.L.; Hwang, S. Short Communication: Cultivation of Lentinus edodes Mycelia Using Whey Permeate as an Alternative Growth Substrate. J. Dairy Sci. 2006, 89, 1113-1115. [CrossRef]

127. Song, M.; Kim, N.; Lee, S.; Hwang, S. Use of Whey Permeate for Cultivating Ganoderma lucidum Mycelia. J. Dairy Sci. 2007, 90, 2141-2146. [CrossRef] [PubMed]

128. Lee, H.; Song, M.; Hwang, S. Optimizing bioconversion of deproteinated cheese whey to mycelia of Ganoderma lucidum. Process Biochem. 2003, 38, 1685-1693. [CrossRef]

129. Lee, H.; Song, M.; Yu, Y.; Hwang, S. Production of Ganoderma lucidum mycelium using cheese whey as an alternative substrate: Response surface analysis and biokinetics. BioChem. Eng. J. 2003, 15, 93-99. [CrossRef]

130. Sanodiya, B.S.; Thakur, G.S.; Baghel, R.K.; Prasad, G.B.; Bisen, P.S. Ganoderma lucidum: A potent pharmacological macrofungus. Curr. Pharm. Biotechnol. 2009, 10, 717-742. [CrossRef]

131. Shao, P.; Xuan, S.; Wu, W.; Qu, L. Encapsulation efficiency and controlled release of Ganoderma lucidum polysaccharide microcapsules by spray drying using different combinations of wall materials. Int. J. Biol. Macromol. 2019, 125, 962-969. [CrossRef]

132. Papadaki, A.; Diamantopoulou, P.; Papanikolaou, S.; Philippoussis, A. Evaluation of Biomass and Chitin Production of Morchella Mushrooms Grown on Starch-Based Substrates. Foods 2019, 8, 239. [CrossRef] [PubMed]

133. Kosaric, N.; Miyata, N. Growth of morel mushroom mycelium in cheese whey. J. Dairy Res. 1981, 48, $149-162$. [CrossRef]

134. Caporgno, M.P.; Mathys, A. Trends in Microalgae Incorporation into Innovative Food Products with Potential Health Benefits. Front. Nutr. 2018, 5, 58. [CrossRef] [PubMed]

135. Beheshtipour, H.; Mortazavian, A.M.; Mohammadi, R.; Sohrabvandi, S.; Khosravi-Darani, K. Supplementation of Spirulina platensis and Chlorella vulgaris Algae into Probiotic Fermented Milks. Compr. Rev. Food Sci. Food Saf. 2013, 12, 144-154. [CrossRef]

136. Abreu, A.P.; Fernandes, B.; Vicente, A.A.; Teixeira, J.; Dragone, G. Mixotrophic cultivation of Chlorella vulgaris using industrial dairy waste as organic carbon source. Bioresour. Technol. 2012, 118, 61-66. [CrossRef] [PubMed]

137. Kulandaivel, S.; Prakash, R.; Anitha, R.; Arunnagendran, N. Comparative studies on biochemical profile of Spirulina platensis and Oscillatoria sp. on synthetic medium and dairy effluent. J. Pure Appl. Microbiol. 2007, 1, 109-112.

138. Vieira Salla, A.C.; Margarites, A.C.; Seibel, F.I.; Holz, L.C.; Brião, V.B.; Bertolin, T.E.; Colla, L.M.; Costa, J.A.V. Increase in the carbohydrate content of the microalgae Spirulina in culture by nutrient starvation and the addition of residues of whey protein concentrate. Bioresour. Technol. 2016, 209, 133-141. [CrossRef] [PubMed]

139. Girard, J.-M.; Roy, M.-L.; Hafsa, M.B.; Gagnon, J.; Faucheux, N.; Heitz, M.; Tremblay, R.; Deschênes, J.-S. Mixotrophic cultivation of green microalgae Scenedesmus obliquus on cheese whey permeate for biodiesel production. Algal Res. 2014, 5, 241-248. [CrossRef] 
140. Afify, A.E.-M.M.R.; El Baroty, G.S.; El Baz, F.K.; Abd El Baky, H.H.; Murad, S.A. Scenedesmus obliquus: Antioxidant and antiviral activity of proteins hydrolyzed by three enzymes. J. Genet. Eng. Biotechnol. 2018, 16, 399-408. [CrossRef] [PubMed]

141. Bleakley, S.; Hayes, M. Algal Proteins: Extraction, Application, and Challenges Concerning Production. Foods 2017, 6, 33. [CrossRef] [PubMed]

142. Cinelli, P.; Schmid, M.; Bugnicourt, E.; Wildner, J.; Bazzichi, A.; Anguillesi, I.; Lazzeri, A. Whey protein layer applied on biodegradable packaging film to improve barrier properties while maintaining biodegradability. Polym. Degrad. Stab. 2014, 108, 151-157. [CrossRef]

143. Tarhan, O.; Spotti, M.J.; Schaffter, S.; Corvalan, C.M.; Campanella, O.H. Rheological and structural characterization of whey protein gelation induced by enzymatic hydrolysis. Food Hydrocoll. 2016, 61, 211-220. [CrossRef]

144. Fu, W.; Nakamura, T. Explaining the texture properties of whey protein isolate/starch co-gels from fracture structures. Biosci. Biotechnol. Biochem. 2017, 81, 839-847. [CrossRef] [PubMed]

145. Khalifa, I.; Nie, R.; Ge, Z.; Li, K.; Li, C. Understanding the shielding effects of whey protein on mulberry anthocyanins: Insights from multispectral and molecular modelling investigations. Int. J. Biol. Macromol. 2018, 119, 116-124. [CrossRef] [PubMed]

146. Andoyo, R.; Dianti Lestari, V.; Mardawati, E.; Nurhadi, B. Fractal Dimension Analysis of Texture Formation of Whey Protein-Based Foods. Int. J. Food Sci. 2018, 2018. [CrossRef] [PubMed]

147. Kurek, M.; Galus, S.; Debeaufort, F. Surface, mechanical and barrier properties of bio-based composite films based on chitosan and whey protein. Food Packag. Shelf Life 2014, 1, 56-67. [CrossRef]

148. Galus, S.; Kadzińska, J. Whey protein edible films modified with almond and walnut oils. Food Hydrocoll. 2016, 52, 78-86. [CrossRef]

149. Barba, C.; Eguinoa, A.; Maté, J.I. Preparation and characterization of $\beta$-cyclodextrin inclusion complexes as a tool of a controlled antimicrobial release in whey protein edible films. LWT Food Sci. Technol. 2015, 64, 1362-1369. [CrossRef]

150. Boyacı, D.; Korel, F.; Yemenicioğlu, A. Development of activate-at-home-type edible antimicrobial films: An example $\mathrm{pH}$-triggering mechanism formed for smoked salmon slices using lysozyme in whey protein films. Food Hydrocoll. 2016, 60, 170-178. [CrossRef]

151. Schmid, M.; Merzbacher, S.; Brzoska, N.; Müller, K.; Jesdinszki, M. Improvement of Food Packaging-Related Properties of Whey Protein Isolate-Based Nanocomposite Films and Coatings by Addition of Montmorillonite Nanoplatelets. Front. Mater. 2017, 4. [CrossRef]

152. Azeredo, H.M.C.; Waldron, K.W. Crosslinking in polysaccharide and protein films and coatings for food contact-A review. Trends Food Sci. Technol. 2016, 52, 109-122. [CrossRef]

153. Jiang, S.-J.; Zhang, T.; Song, Y.; Qian, F.; Tuo, Y.; Mu, G. Mechanical properties of whey protein concentrate based film improved by the coexistence of nanocrystalline cellulose and transglutaminase. Int. J. Biol. Macromol. 2019, 126, 1266-1272. [CrossRef] [PubMed]

154. Qazanfarzadeh, Z.; Kadivar, M. Properties of whey protein isolate nanocomposite films reinforced with nanocellulose isolated from oat husk. Int. J. Biol. Macromol. 2016, 91, 1134-1140. [CrossRef] [PubMed]

155. Hassannia-Kolaee, M.; Khodaiyan, F.; Pourahmad, R.; Shahabi-Ghahfarrokhi, I. Development of ecofriendly bionanocomposite: Whey protein isolate/pullulan films with nano-SiO${ }_{2}$. Int. J. Biol. Macromol. 2016, 86, 139-144. [CrossRef] [PubMed]

156. Zhang, W.; Chen, J.; Chen, Y.; Xia, W.; Xiong, Y.L.; Wang, H. Enhanced physicochemical properties of chitosan/whey protein isolate composite film by sodium laurate-modified $\mathrm{TiO}_{2}$ nanoparticles. Carbohydr. Polym. 2016, 138, 59-65. [CrossRef]

157. Basiak, E.; Lenart, A.; Debeaufort, F. Effects of carbohydrate/protein ratio on the microstructure and the barrier and sorption properties of wheat starch-whey protein blend edible films. J. Sci. Food Agric. 2017, 97, 858-867. [CrossRef] [PubMed]

158. Tsai, M.-J.; Weng, Y.-M. Novel edible composite films fabricated with whey protein isolate and zein: Preparation and physicochemical property evaluation. LWT 2019, 101, 567-574. [CrossRef]

159. Oymaci, P.; Altinkaya, S.A. Improvement of barrier and mechanical properties of whey protein isolate based food packaging films by incorporation of zein nanoparticles as a novel bionanocomposite. Food Hydrocoll. 2016, 54, 1-9. [CrossRef] 
160. Bahram, S.; Rezaei, M.; Soltani, M.; Kamali, A.; Ojagh, S.M.; Abdollahi, M. Whey Protein Concentrate Edible Film Activated with Cinnamon Essential Oil. J. Food Process. Preserv. 2014, 38, 1251-1258. [CrossRef]

161. Khanzadi, M.; Jafari, S.M.; Mirzaei, H.; Chegini, F.K.; Maghsoudlou, Y.; Dehnad, D. Physical and mechanical properties in biodegradable films of whey protein concentrate-pullulan by application of beeswax. Carbohydr. Polym. 2015, 118, 24-29. [CrossRef]

162. Rantamäki, P.; Loimaranta, V.; Vasara, E.; Latva-Koivisto, J.; Korhonen, H.; Tenovuo, J.; Marnila, P. Edible films based on milk proteins release effectively active immunoglobulins. Food Qual. Saf. 2019, 3, $23-34$. [CrossRef]

163. Piccirilli, G.N.; Soazo, M.; Pérez, L.M.; Delorenzi, N.J.; Verdini, R.A. Effect of storage conditions on the physicochemical characteristics of edible films based on whey protein concentrate and liquid smoke. Food Hydrocoll. 2019, 87, 221-228. [CrossRef]

164. Pereira, R.C.; de Deus Souza Carneiro, J.; Borges, S.V.; Assis, O.B.G.; Alvarenga, G.L. Preparation and Characterization of Nanocomposites from Whey Protein Concentrate Activated with Lycopene. J. Food Sci. 2016, 81, E637-E642. [CrossRef] [PubMed]

165. Soukoulis, C.; Behboudi-Jobbehdar, S.; Macnaughtan, W.; Parmenter, C.; Fisk, I.D. Stability of Lactobacillus rhamnosus GG incorporated in edible films: Impact of anionic biopolymers and whey protein concentrate. Food Hydrocoll. 2017, 70, 345-355. [CrossRef] [PubMed]

166. Cecchini, J.P.; Spotti, M.J.; Piagentini, A.M.; Milt, V.G.; Carrara, C.R. Development of edible films obtained from submicron emulsions based on whey protein concentrate, oil/beeswax and brea gum. Food Sci. Technol. Int. 2017, 23, 371-381. [CrossRef] [PubMed]

167. Ribeiro-Santos, R.; de Melo, N.R.; Andrade, M.; Azevedo, G.; Machado, A.V.; Carvalho-Costa, D.; Sanches-Silva, A. Whey protein active films incorporated with a blend of essential oils: Characterization and effectiveness. Packag. Technol. Sci. 2018, 31, 27-40. [CrossRef]

168. Pereira, R.C.; Carneiro, J.d.D.S.; Assis, O.B.; Borges, S.V. Mechanical and structural characterization of whey protein concentrate/montmorillonite/lycopene films. J. Sci. Food Agric. 2017, 97, 4978-4986. [CrossRef]

169. Pérez, L.M.; Piccirilli, G.N.; Delorenzi, N.J.; Verdini, R.A. Effect of different combinations of glycerol and/or trehalose on physical and structural properties of whey protein concentrate-based edible films. Food Hydrocoll. 2016, 56, 352-359. [CrossRef]

170. Ganiari, S.; Choulitoudi, E.; Oreopoulou, V. Edible and active films and coatings as carriers of natural antioxidants for lipid food. Trends Food Sci. Technol. 2017, 68, 70-82. [CrossRef]

171. Andrade, M.A.; Ribeiro-Santos, R.; Costa Bonito, M.C.; Saraiva, M.; Sanches-Silva, A. Characterization of rosemary and thyme extracts for incorporation into a whey protein based film. LWT 2018, 92, 497-508. [CrossRef]

172. Ribeiro-Santos, R.; Andrade, M.; de Melo, N.R.; dos Santos, F.R.; Neves, I.d.A.; de Carvalho, M.G.; Sanches-Silva, A. Biological activities and major components determination in essential oils intended for a biodegradable food packaging. Ind. Crop. Prod. 2017, 97, 201-210. [CrossRef]

173. Nicolai, T. Formation and functionality of self-assembled whey protein microgels. Colloids Surf. B Biointerfaces 2016, 137, 32-38. [CrossRef] [PubMed]

174. Abaee, A.; Madadlou, A. Niosome-loaded cold-set whey protein hydrogels. Food Chem. 2016, 196, $106-113$. [CrossRef] [PubMed]

175. Banerjee, S.; Bhattacharya, S. Food Gels: Gelling Process and New Applications. Crit. Rev. Food Sci. Nutr. 2012, 52, 334-346. [CrossRef] [PubMed]

176. Nguyen, B.T.; Chassenieux, C.; Nicolai, T.; Schmitt, C. Effect of the $\mathrm{pH}$ and $\mathrm{NaCl}$ on the microstructure and rheology of mixtures of whey protein isolate and casein micelles upon heating. Food Hydrocoll. 2017, 70, 114-122. [CrossRef]

177. Kharlamova, A.; Chassenieux, C.; Nicolai, T. Acid-induced gelation of whey protein aggregates: Kinetics, gel structure and rheological properties. Food Hydrocoll. 2018, 81, 263-272. [CrossRef]

178. Lam, C.W.Y.; Ikeda, S. Physical Properties of Heat-induced Whey Protein Aggregates Formed at pH 5.5 and 7.0. Food Sci. Technol. Res. 2017, 23, 595-601. [CrossRef]

179. Lazidis, A.; Hancocks, R.D.; Spyropoulos, F.; Kreuß, M.; Berrocal, R.; Norton, I.T. Whey protein fluid gels for the stabilisation of foams. Food Hydrocoll. 2016, 53, 209-217. [CrossRef] 
180. Alavi, F.; Momen, S.; Emam-Djomeh, Z.; Salami, M.; Moosavi-Movahedi, A.A. Radical cross-linked whey protein aggregates as building blocks of non-heated cold-set gels. Food Hydrocoll. 2018, 81, 429-441. [CrossRef]

181. Kharlamova, A.; Nicolai, T.; Chassenieux, C. Calcium-induced gelation of whey protein aggregates: Kinetics, structure and rheological properties. Food Hydrocoll. 2018, 79, 145-157. [CrossRef]

182. Ren, F.; Dong, D.; Yu, B.; Hou, Z.-h.; Cui, B. Rheology, thermal properties, and microstructure of heat-induced gel of whey protein-acetylated potato starch. Starch Stärke 2017, 69, 1600344. [CrossRef]

183. Li, Q.; Zhao, Z. Interaction between lactoferrin and whey proteins and its influence on the heat-induced gelation of whey proteins. Food Chem. 2018, 252, 92-98. [CrossRef] [PubMed]

184. Selig, M.J.; Dar, B.N.; Kierulf, A.; Ravanfar, R.; Rizvi, S.S.H.; Abbaspourrad, A. Modulation of whey protein-kappa carrageenan hydrogel properties via enzymatic protein modification. Food Funct. 2018, 9 , 2313-2319. [CrossRef] [PubMed]

185. Moayyedi, M.; Eskandari, M.H.; Rad, A.H.E.; Ziaee, E.; Khodaparast, M.H.H.; Golmakani, M.-T. Effect of drying methods (electrospraying, freeze drying and spray drying) on survival and viability of microencapsulated Lactobacillus rhamnosus ATCC 7469. J. Funct. Foods 2018, 40, 391-399. [CrossRef]

186. Sogut, E.; Ili Balqis, A.M.; Nur Hanani, Z.A.; Seydim, A.C. The properties of $\kappa$-carrageenan and whey protein isolate blended films containing pomegranate seed oil. Polym. Test. 2019, 77. [CrossRef]

187. Protte, K.; Weiss, J.; Hinrichs, J.; Knaapila, A. Thermally stabilised whey protein-pectin complexes modulate the thermodynamic incompatibility in hydrocolloid matrixes: A feasibility-study on sensory and rheological characteristics in dairy desserts. LWT 2019, 105, 336-343. [CrossRef]

188. Rajam, R.; Anandharamakrishnan, C. Microencapsulation of Lactobacillus plantarum (MTCC 5422) with fructooligosaccharide as wall material by spray drying. LWT Food Sci. Technol. 2015, 60, 773-780. [CrossRef]

189. Su, J.; Wang, X.; Li, W.; Chen, L.; Zeng, X.; Huang, Q.; Hu, B. Enhancing the Viability of Lactobacillus plantarum as Probiotics through Encapsulation with High Internal Phase Emulsions Stabilized with Whey Protein Isolate Microgels. J. Agric. Food Chem. 2018, 66, 12335-12343. [CrossRef]

190. Kwiecień, I.; Kwiecień, M. Application of Polysaccharide-Based Hydrogels as Probiotic Delivery Systems. Gels 2018, 4, 47. [CrossRef]

191. O'Neill, G.J.; Egan, T.; Jacquier, J.C.; O'Sullivan, M.; Dolores O'Riordan, E. Whey microbeads as a matrix for the encapsulation and immobilisation of riboflavin and peptides. Food Chem. 2014, 160, 46-52. [CrossRef]

192. Abbasi, A.; Emam-Djomeh, Z.; Mousavi, M.A.E.; Davoodi, D. Stability of vitamin D3 encapsulated in nanoparticles of whey protein isolate. Food Chem. 2014, 143, 379-383. [CrossRef] [PubMed]

193. Rojas-Moreno, S.; Osorio-Revilla, G.; Gallardo-Velázquez, T.; Cárdenas-Bailón, F.; Meza-Márquez, G. Effect of the cross-linking agent and drying method on encapsulation efficiency of orange essential oil by complex coacervation using whey protein isolate with different polysaccharides. J. Microencapsul. 2018, 35, 165-180. [CrossRef] [PubMed]

194. Mohammadian, M.; Salami, M.; Momen, S.; Alavi, F.; Emam-Djomeh, Z. Fabrication of curcumin-loaded whey protein microgels: Structural properties, antioxidant activity, and in vitro release behavior. LWT 2019, 103, 94-100. [CrossRef]

195. Raei, M.; Shahidi, F.; Farhoodi, M.; Jafari, S.M.; Rafe, A. Application of whey protein-pectin nano-complex carriers for loading of lactoferrin. Int. J. Biol. Macromol. 2017, 105, 281-291. [CrossRef] [PubMed]

196. Assadpour, E.; Maghsoudlou, Y.; Jafari, S.-M.; Ghorbani, M.; Aalami, M. Optimization of folic acid nano-emulsification and encapsulation by maltodextrin-whey protein double emulsions. Int. J. Biol. Macromol. 2016, 86, 197-207. [CrossRef] [PubMed]

197. Fang, Z.; Bao, H.; Ni, Y.; Choijilsuren, N.; Liang, L. Partition and digestive stability of $\alpha$-tocopherol and resveratrol/naringenin in whey protein isolate emulsions. Int. Dairy J. 2019, 93, 116-123. [CrossRef]

198. Nourbakhsh, H.; Madadlou, A.; Emam-Djomeh, Z.; Wang, Y.-C.; Gunasekaran, S.; Mousavi, M.E. One-Pot Procedure for Recovery of Gallic Acid from Wastewater and Encapsulation within Protein Particles. J. Agric. Food Chem. 2016, 64, 1575-1582. [CrossRef]

199. Jain, A.; Sharma, G.; Ghoshal, G.; Kesharwani, P.; Singh, B.; Shivhare, U.S.; Katare, O.P. Lycopene loaded whey protein isolate nanoparticles: An innovative endeavor for enhanced bioavailability of lycopene and anti-cancer activity. Int. J. Pharm. 2018, 546, 97-105. [CrossRef] 
200. O'Neill, G.J.; Egan, T.; Jacquier, J.C.; O'Sullivan, M.; Dolores O'Riordan, E. Kinetics of immobilisation and release of tryptophan, riboflavin and peptides from whey protein microbeads. Food Chem. 2015, 180, 150-155. [CrossRef]

201. Alavi, F.; Emam-Djomeh, Z.; Yarmand, M.S.; Salami, M.; Momen, S.; Moosavi-Movahedi, A.A. Cold gelation of curcumin loaded whey protein aggregates mixed with k-carrageenan: Impact of gel microstructure on the gastrointestinal fate of curcumin. Food Hydrocoll. 2018, 85, 267-280. [CrossRef]

202. Mohammadian, M.; Salami, M.; Momen, S.; Alavi, F.; Emam-Djomeh, Z.; Moosavi-Movahedi, A.A. Enhancing the aqueous solubility of curcumin at acidic condition through the complexation with whey protein nanofibrils. Food Hydrocoll. 2019, 87, 902-914. [CrossRef]

203. Mohammadian, M.; Madadlou, A. Cold-set hydrogels made of whey protein nanofibrils with different divalent cations. Int. J. Biol. Macromol. 2016, 89, 499-506. [CrossRef] [PubMed]

204. Mohammadian, M.; Salami, M.; Emam-Djomeh, Z.; Momen, S.; Moosavi-Movahedi, A.A. Gelation of oil-in-water emulsions stabilized by heat-denatured and nanofibrillated whey proteins through ion bridging or citric acid-mediated cross-linking. Int. J. Biol. Macromol. 2018, 120, 2247-2258. [CrossRef]

205. Mantovani, R.A.; Fattori, J.; Michelon, M.; Cunha, R.L. Formation and pH-stability of whey protein fibrils in the presence of lecithin. Food Hydrocoll. 2016, 60, 288-298. [CrossRef]

206. Hashemi, B.; Madadlou, A.; Salami, M. Functional and in vitro gastric digestibility of the whey protein hydrogel loaded with nanostructured lipid carriers and gelled via citric acid-mediated crosslinking. Food Chem. 2017, 237, 23-29. [CrossRef] [PubMed]

207. Zhu, J.; Sun, X.; Wang, S.; Xu, Y.; Wang, D. Formation of nanocomplexes comprising whey proteins and fucoxanthin: Characterization, spectroscopic analysis, and molecular docking. Food Hydrocoll. 2017, 63, 391-403. [CrossRef]

208. Bamba, B.S.B.; Shi, J.; Tranchant, C.C.; Xue, S.J.; Forney, C.F.; Lim, L.-T.; Xu, W.; Xu, G. Coencapsulation of Polyphenols and Anthocyanins from Blueberry Pomace by Double Emulsion Stabilized by Whey Proteins: Effect of Homogenization Parameters. Molecules 2018, 23, 2525. [CrossRef] [PubMed]

209. Chotiko, A.; Sathivel, S. Releasing characteristics of anthocyanins extract in pectin-whey protein complex microcapsules coated with zein. J. Food Sci. Technol. 2017, 54, 2059-2066. [CrossRef]

210. Rocha, J.D.C.G.; Viana, K.W.C.; Mendonca, A.C.; Neves, N.D.A.; Carvalho, A.F.D.; Minim, V.P.R.; Barros, F.A.R.D.; Stringheta, P.C. Protein beverages containing anthocyanins of jabuticaba. Food Sci. Technol. 2019, 39, 112-119. [CrossRef]

211. Shen, X.; Zhao, C.; Lu, J.; Guo, M. Physicochemical Properties of Whey-Protein-Stabilized Astaxanthin Nanodispersion and Its Transport via a Caco-2 Monolayer. J. Agric. Food Chem. 2018, 66, 1472-1478. [CrossRef]

212. Ramos, O.L.; Pereira, R.N.; Martins, A.; Rodrigues, R.; Fuciños, C.; Teixeira, J.A.; Pastrana, L.; Malcata, F.X.; Vicente, A.A. Design of whey protein nanostructures for incorporation and release of nutraceutical compounds in food. Crit. Rev. Food Sci. Nutr. 2017, 57, 1377-1393. [CrossRef] [PubMed]

213. Sun, W.-W.; Yu, S.-J.; Zeng, X.-A.; Yang, X.-Q.; Jia, X. Properties of whey protein isolate-dextran conjugate prepared using pulsed electric field. Food Res. Int. 2011, 44, 1052-1058. [CrossRef]

214. Perusko, M.; Al-Hanish, A.; Cirkovic Velickovic, T.; Stanic-Vucinic, D. Macromolecular crowding conditions enhance glycation and oxidation of whey proteins in ultrasound-induced Maillard reaction. Food Chem. 2015, 177, 248-257. [CrossRef] [PubMed]

215. Díaz, O.; Candia, D.; Cobos, Á. Effects of ultraviolet radiation on properties of films from whey protein concentrate treated before or after film formation. Food Hydrocoll. 2016, 55, 189-199. [CrossRef]

216. Kutzli, I.; Gibis, M.; Baier, S.K.; Weiss, J. Formation of Whey Protein Isolate (WPI)-Maltodextrin Conjugates in Fibers Produced by Needleless Electrospinning. J. Agric. Food Chem. 2018, 66, 10283-10291. [CrossRef]

217. Zhong, J.; Mohan, S.D.; Bell, A.; Terry, A.; Mitchell, G.R.; Davis, F.J. Electrospinning of food-grade nanofibres from whey protein. Int. J. Biol. Macromol. 2018, 113, 764-773. [CrossRef]

218. Colín-Orozco, J.; Zapata-Torres, M.; Rodríguez-Gattorno, G.; Pedroza-Islas, R. Properties of Poly (ethylene oxide)/whey Protein Isolate Nanofibers Prepared by Electrospinning. Food Biophys. 2015, 10, 134-144. [CrossRef]

219. Drosou, C.; Krokida, M.; Biliaderis, C.G. Composite pullulan-whey protein nanofibers made by electrospinning: Impact of process parameters on fiber morphology and physical properties. Food Hydrocoll. 2018, 77, 726-735. [CrossRef] 
220. Mendes, A.C.; Stephansen, K.; Chronakis, I.S. Electrospinning of food proteins and polysaccharides. Food Hydrocoll. 2017, 68, 53-68. [CrossRef]

221. Vieira da Silva, S.; Sogari Picolotto, R.; Wagner, R.; dos Santos Richards, N.S.P.; Smanioto Barin, J. Elemental (Macro- and Microelements) and Amino Acid Profile of Milk Proteins Commercialized in Brazil and Their Nutritional Value. J. Food Nutr. Res. 2015, 3, 430-436.

222. Devries, M.C.; Phillips, S.M. Supplemental Protein in Support of Muscle Mass and Health: Advantage Whey. J. Food Sci. 2015, 80, A8-A15. [CrossRef] [PubMed]

223. Trachootham, D.; Lu, W.; Ogasawara, M.A.; Nilsa, R.-D.V.; Huang, P. Redox regulation of cell survival. Antioxid Redox Signal 2008, 10, 1343-1374. [CrossRef] [PubMed]

224. Pedroso, J.A.B.; Zampieri, T.T.; Donato, J. Reviewing the Effects of 1-Leucine Supplementation in the Regulation of Food Intake, Energy Balance, and Glucose Homeostasis. Nutrients 2015, 7, 3914-3937. [CrossRef] [PubMed]

225. Nie, C.; He, T.; Zhang, W.; Zhang, G.; Ma, X. Branched Chain Amino Acids: Beyond Nutrition Metabolism. Int. J. Mol. Sci. 2018, 19, 954. [CrossRef] [PubMed]

226. Moura, C.S.; Lollo, P.C.B.; Morato, P.N.; Risso, E.M.; Amaya-Farfan, J. Bioactivity of food peptides: Biological response of rats to bovine milk whey peptides following acute exercise. Food Nutr. Res. 2017, 61, 1290740. [CrossRef] [PubMed]

227. Ikwegbue, P.C.; Masamba, P.; Oyinloye, B.E.; Kappo, A.P. Roles of Heat Shock Proteins in Apoptosis, Oxidative Stress, Human Inflammatory Diseases, and Cancer. Pharmaceuticals 2018, 11, 2. [CrossRef] [PubMed]

228. McPherson, R.A.; Hardy, G. Clinical and nutritional benefits of cysteine-enriched protein supplements. Curr. Opin. Clin. Nutr. Metab. Care 2011, 14, 562-568. [CrossRef]

229. Winter, A.N.; Ross, E.K.; Daliparthi, V.; Sumner, W.A.; Kirchhof, D.M.; Manning, E.; Wilkins, H.M.; Linseman, D.A. A Cystine-Rich Whey Supplement (Immunocal(R)) Provides Neuroprotection from Diverse Oxidative Stress-Inducing Agents In Vitro by Preserving Cellular Glutathione. Oxid. Med. Cell. Longev. 2017, 2017, 3103272. [CrossRef]

230. Gao, X.; Sanderson, S.M.; Dai, Z.; Reid, M.A.; Cooper, D.E.; Lu, M.; Richie, J.P.; Ciccarella, A.; Calcagnotto, A.; Mikhael, P.G.; et al. Dietary methionine restriction targets one carbon metabolism in humans and produces broad therapeutic responses in cancer. bioRxiv 2019, 627364. [CrossRef]

231. Zheng, G.; Liu, H.; Zhu, Z.; Zheng, J.; Liu, A. Selenium modification of $\beta$-lactoglobulin $(\beta$-Lg) and its biological activity. Food Chem. 2016, 204, 246-251. [CrossRef]

232. Sah, B.N.P.; McAinch, A.J.; Vasiljevic, T. Modulation of bovine whey protein digestion in gastrointestinal tract: A comprehensive review. Int. Dairy J. 2016, 62, 10-18. [CrossRef]

233. Corrêa, A.P.F.; Daroit, D.J.; Fontoura, R.; Meira, S.M.M.; Segalin, J.; Brandelli, A. Hydrolysates of sheep cheese whey as a source of bioactive peptides with antioxidant and angiotensin-converting enzyme inhibitory activities. Peptides 2014, 61, 48-55. [CrossRef] [PubMed]

234. El-Desouky, W.I.; Mahmoud, A.H.; Abbas, M.M. Antioxidant potential and hypolipidemic effect of whey protein against gamma irradiation induced damages in rats. Appl. Radiat. Isot. 2017, 129, 103-107. [CrossRef] [PubMed]

235. Yao, C.K.; Muir, J.G.; Gibson, P.R. Review article: Insights into colonic protein fermentation, its modulation and potential health implications. Aliment. Pharmacol. Ther. 2016, 43, 181-196. [CrossRef] [PubMed]

236. Fonseca, D.P.; Khalil, N.M.; Mainardes, R.M. Bovine serum albumin-based nanoparticles containing resveratrol: Characterization and antioxidant activity. J. Drug Deliv. Sci. Technol. 2017, 39, 147-155. [CrossRef]

237. Park, Y.W.; Nam, M.S. Bioactive Peptides in Milk and Dairy Products: A Review. Korean J. Food Sci. Anim. Resour. 2015, 35, 831-840. [CrossRef] [PubMed]

238. Lagrange, V.; Clark, D.C. Chapter 15-Nutritive and Therapeutic Aspects of Whey Proteins. In Whey Proteins; Deeth, H.C., Bansal, N., Eds.; Academic Press: Cambridge, MA, USA, 2019; pp. 549-577.

239. Tong, X.; Li, W.; Xu, J.-Y.; Han, S.; Qin, L.-Q. Effects of whey protein and leucine supplementation on insulin resistance in non-obese insulin-resistant model rats. Nutrition 2014, 30, 1076-1080. [CrossRef]

240. Akhavan, T.; Luhovyy, B.L.; Panahi, S.; Kubant, R.; Brown, P.H.; Anderson, G.H. Mechanism of action of pre-meal consumption of whey protein on glycemic control in young adults. J. Nutr. Biochem. 2014, 25, 36-43. [CrossRef] 
241. Bamdad, F.; Bark, S.; Kwon, C.H.; Suh, J.-W.; Sunwoo, H. Anti-Inflammatory and Antioxidant Properties of Peptides Released from $\beta$-Lactoglobulin by High Hydrostatic Pressure-Assisted Enzymatic Hydrolysis. Molecules 2017, 22, 949. [CrossRef]

242. Alvarado, Y.; Muro, C.; Illescas, J.; Díaz, M.d.C.; Riera, F. Encapsulation of Antihypertensive Peptides from Whey Proteins and Their Releasing in Gastrointestinal Conditions. Biomolecules 2019, 9, 164. [CrossRef]

243. Tahavorgar, A.; Vafa, M.; Shidfar, F.; Gohari, M.; Heydari, I. Whey protein preloads are more beneficial than soy protein preloads in regulating appetite, calorie intake, anthropometry, and body composition of overweight and obese men. Nutr. Res. 2014, 34, 856-861. [CrossRef] [PubMed]

244. Tahavorgar, A.; Vafa, M.; Shidfar, F.; Gohari, M.; Heydari, I. Beneficial effects of whey protein preloads on some cardiovascular diseases risk factors of overweight and obese men are stronger than soy protein preloads-A randomized clinical trial. J. Nutr. Intermed. Metab. 2015, 2, 69-75. [CrossRef]

245. Lollo, P.C.B.; Amaya-Farfan, J.; Faria, I.C.; Salgado, J.V.V.; Chacon-Mikahil, M.P.T.; Cruz, A.G.; Oliveira, C.A.F.; Montagner, P.C.; Arruda, M. Hydrolysed whey protein reduces muscle damage markers in Brazilian elite soccer players compared with whey protein and maltodextrin. A twelve-week in-championship intervention. Int. Dairy J. 2014, 34, 19-24. [CrossRef]

246. Cheung, L.K.Y.; Aluko, R.E.; Cliff, M.A.; Li-Chan, E.C.Y. Effects of exopeptidase treatment on antihypertensive activity and taste attributes of enzymatic whey protein hydrolysates. J. Funct. Foods 2015, 13, 262-275. [CrossRef]

247. Kimura, Y.; Sumiyoshi, M.; Kobayashi, T. Whey Peptides Prevent Chronic Ultraviolet B Radiation-Induced Skin Aging in Melanin-Possessing Male Hairless Mice. J. Nutr. 2013, 144, 27-32. [CrossRef]

248. Dalziel, J.E.; Anderson, R.C.; Bassett, S.A.; Lloyd-West, C.M.; Haggarty, N.W.; Roy, N.C. Influence of Bovine Whey Protein Concentrate and Hydrolysate Preparation Methods on Motility in the Isolated Rat Distal Colon. Nutrients 2016, 8, 809. [CrossRef]

249. Nilaweera, K.N.; Cabrera-Rubio, R.; Speakman, J.R.; O'Connor, P.M.; McAuliffe, A.; Guinane, C.M.; Lawton, E.M.; Crispie, F.; Aguilera, M.; Stanley, M.; et al. Whey protein effects on energy balance link the intestinal mechanisms of energy absorption with adiposity and hypothalamic neuropeptide gene expression. Am. J. Physiol. Endocrinol. Metab. 2017, 313, E1-E11. [CrossRef]

250. Hwang, J.S.; Han, S.G.; Lee, C.H.; Seo, H.G. Whey Protein Attenuates Angiotensin II-Primed Premature Senescence of Vascular Smooth Muscle Cells through Upregulation of SIRT1. Korean J. Food Sci. Anim. Resour. 2017, 37, 917-925. [CrossRef]

251. Garg, G.; Singh, S.; Singh, A.K.; Rizvi, S.I. Whey protein concentrate supplementation protects rat brain against aging-induced oxidative stress and neurodegeneration. Appl. Physiol. Nutr. Metab. 2017, 43, 437-444. [CrossRef]

252. Flaim, C.; Kob, M.; Di Pierro, A.M.; Herrmann, M.; Lucchin, L. Effects of a whey protein supplementation on oxidative stress, body composition and glucose metabolism among overweight people affected by diabetes mellitus or impaired fasting glucose: A pilot study. J. Nutr. Biochem. 2017, 50, 95-102. [CrossRef]

253. Ney, D.M.; Blank, R.D.; Hansen, K.E. Advances in the nutritional and pharmacological management of phenylketonuria. Curr. Opin. Clin. Nutr. Metab. Care 2014, 17, 61-68. [CrossRef] [PubMed]

254. Brown, M.A.; Stevenson, E.J.; Howatson, G. Whey protein hydrolysate supplementation accelerates recovery from exercise-induced muscle damage in females. Appl. Physiol. Nutr. Metab. 2017, 43, 324-330. [CrossRef] [PubMed]

255. Shirato, M.; Tsuchiya, Y.; Sato, T.; Hamano, S.; Gushiken, T.; Kimura, N.; Ochi, E. Effects of combined $\beta$-hydroxy- $\beta$-methylbutyrate $(\mathrm{HMB})$ and whey protein ingestion on symptoms of eccentric exercise-induced muscle damage. J. Int. Soc. Sports Nutr. 2016, 13, 7. [CrossRef] [PubMed]

256. Moura, C.S.; Lollo, P.C.B.; Morato, P.N.; Nisishima, L.H.; Carneiro, E.M.; Amaya-Farfan, J. Whey Protein Hydrolysate Enhances HSP90 but Does Not Alter HSP60 and HSP25 in Skeletal Muscle of Rats. PLoS ONE 2014, 9, e83437. [CrossRef]

257. Korhonen, H.; Pihlanto, A. Bioactive peptides: Production and functionality. Int. Dairy J. 2006, 16, 945-960. [CrossRef]

258. Muro Urista, C.; Alvarez Fernandez, R.; Riera Rodriguez, F.; Arana Cuenca, A.; Tellez Jurado, A. Review: Production and functionality of active peptides from milk. Food Sci. Technol. Int. 2011, 17, 293-317. [CrossRef] 
259. Welsh, G.; Ryder, K.; Brewster, J.; Walker, C.; Mros, S.; Bekhit, A.E.-D.A.; McConnell, M.; Carne, A. Comparison of bioactive peptides prepared from sheep cheese whey using a food-grade bacterial and a fungal protease preparation. Int. J. Food Sci. Technol. 2017, 52, 1252-1259. [CrossRef]

260. Rocha, G.F.; Kise, F.; Rosso, A.M.; Parisi, M.G. Potential antioxidant peptides produced from whey hydrolysis with an immobilized aspartic protease from Salpichroa origanifolia fruits. Food Chem. 2017, 237, 350-355. [CrossRef]

261. Hernández-Ledesma, B.; Hsieh, C.-C.; Martínez-Villaluenga, C. Food Bioactive Compounds against Diseases of the 21st Century 2016. BioMed Res. Int. 2017, 2017. [CrossRef]

262. Brandelli, A.; Daroit, D.J.; Corrêa, A.P.F. Whey as a source of peptides with remarkable biological activities. Food Res. Int. 2015, 73, 149-161. [CrossRef]

263. Brumini, D.; Criscione, A.; Bordonaro, S.; Vegarud, G.E.; Marletta, D. Whey proteins and their antimicrobial properties in donkey milk: A brief review. Dairy Sci. Technol. 2016, 96, 1-14. [CrossRef]

264. Mohan, A.; Udechukwu, M.C.; Rajendran, S.R.C.K.; Udenigwe, C.C. Modification of peptide functionality during enzymatic hydrolysis of whey proteins. RSC Adv. 2015, 5, 97400-97407. [CrossRef]

265. Adams, R.L.; Broughton, K.S. Insulinotropic Effects of Whey: Mechanisms of Action, Recent Clinical Trials, and Clinical Applications. Ann. Nutr. Metab. 2016, 69, 56-63. [CrossRef] [PubMed]

266. Dullius, A.; Goettert, M.I.; de Souza, C.F.V. Whey protein hydrolysates as a source of bioactive peptides for functional foods-Biotechnological facilitation of industrial scale-up. J. Funct. Foods 2018, 42, 58-74. [CrossRef]

267. Agyei, D.; Ongkudon, C.M.; Wei, C.Y.; Chan, A.S.; Danquah, M.K. Bioprocess challenges to the isolation and purification of bioactive peptides. Food Bioprod. Process. 2016, 98, 244-256. [CrossRef]

268. Iltchenco, S.; Preci, D.; Bonifacino, C.; Fraguas, E.F.; Steffens, C.; Panizzolo, L.A.; Colet, R.; Fernandes, I.A.; Abirached, C.; Valduga, E.; et al. Whey protein concentration by ultrafiltration and study of functional properties. Ciênc. Rural 2018, 48. [CrossRef]

269. Nongonierma, A.B.; FitzGerald, R.J. Strategies for the discovery and identification of food protein-derived biologically active peptides. Trends Food Sci. Technol. 2017, 69, 289-305. [CrossRef]

270. Dupont, D. Peptidomic as a tool for assessing protein digestion. Curr. Opin. Food Sci. 2017, 16, 53-58. [CrossRef]

271. Valdés, A.; Cifuentes, A.; León, C. Foodomics evaluation of bioactive compounds in foods. TrAC Trends Anal. Chem. 2017, 96, 2-13. [CrossRef]

272. Agyei, D.; Tsopmo, A.; Udenigwe, C.C. Bioinformatics and peptidomics approaches to the discovery and analysis of food-derived bioactive peptides. Anal. Bioanal. Chem. 2018, 410, 3463-3472. [CrossRef]

273. de Jong, E.; Higson, A.; Walsh, P.; Wellissch, M. Bio-based chemicals: Value added products from biorefineries. 2012. Available online: http://www.iea-bioenergy.task42-biorefineries.com/publications/reports (accessed on 15 June 2019).

274. De Corato, U.; De Bari, I.; Viola, E.; Pugliese, M. Assessing the main opportunities of integrated biorefining from agro-bioenergy co/by-products and agroindustrial residues into high-value added products associated to some emerging markets: A review. Renew. Sustain. Energy Rev. 2018, 88, 326-346. [CrossRef]

275. Matsakas, L.; Gao, Q.; Jansson, S.; Rova, U.; Christakopoulos, P. Green conversion of municipal solid wastes into fuels and chemicals. Electron. J. Biotechnol. 2017, 26, 69-83. [CrossRef]

276. Iriondo-DeHond, M.; Miguel, E.; Del Castillo, M.D. Food Byproducts as Sustainable Ingredients for Innovative and Healthy Dairy Foods. Nutrients 2018, 10, 1358. [CrossRef] [PubMed]

277. Fermoso, F.G.; Serrano, A.; Alonso-Fariñas, B.; Fernández-Bolaños, J.; Borja, R.; Rodríguez-Gutiérrez, G. Valuable Compound Extraction, Anaerobic Digestion, and Composting: A Leading Biorefinery Approach for Agricultural Wastes. J. Agric. Food Chem. 2018, 66, 8451-8468. [CrossRef] [PubMed]

278. Popa, V.I. 1-Biomass for Fuels and Biomaterials. In Biomass as Renewable Raw Material to Obtain Bioproducts of High-Tech Value; Popa, V., Volf, I., Eds.; Elsevier: Amsterdam, The Netherlands, 2018; pp. 1-37.

279. Fu, W.; Mathews, A.P. Lactic acid production from lactose by Lactobacillus plantarum: Kinetic model and effects of pH, substrate, and oxygen. BioChem. Eng. J. 1999, 3, 163-170. [CrossRef]

280. Petrov, K.K.; Yankov, D.S.; Beschkov, V.N. Lactic acid fermentation by cells of Lactobacillus rhamnosus immobilizedin polyacrylamide gel. World J. Microbiol. Biotechnol. 2006, 22, 337-345. [CrossRef] 
281. Sørensen, K.I.; Curic-Bawden, M.; Junge, M.P.; Janzen, T.; Johansen, E. Enhancing the Sweetness of Yoghurt through Metabolic Remodeling of Carbohydrate Metabolism in Streptococcus thermophilus and Lactobacillus delbrueckii subsp. bulgaricus. Appl. Environ. Microbiol. 2016, 82, 3683-3692. [CrossRef]

282. Panesar, P.S.; Kennedy, J.F.; Knill, C.J.; Kosseva, M. Production of L(+) lactic acid using Lactobacillus casei from whey. Braz. Arch. Biol. Technol. 2010, 53, 219-226. [CrossRef]

283. Rama, G.R.; Kuhn, D.; Beux, S.; Maciel, M.J.; Volken de Souza, C.F. Potential applications of dairy whey for the production of lactic acid bacteria cultures. Int. Dairy J. 2019, 98, 25-37. [CrossRef]

284. Amaro, T.M.M.M.; Rosa, D.; Comi, G.; Iacumin, L. Prospects for the Use of Whey for Polyhydroxyalkanoate (PHA) Production. Front. Microbiol. 2019, 10, 992. [CrossRef]

285. Brown, K.; Harrison, J.; Bowers, K. Production of Oxalic Acid from Aspergillus niger and Whey Permeate. Water Air Soil Pollut. 2017, 229, 5. [CrossRef]

286. Pasotti, L.; Zucca, S.; Casanova, M.; Micoli, G.; Cusella De Angelis, M.G.; Magni, P. Fermentation of lactose to ethanol in cheese whey permeate and concentrated permeate by engineered Escherichia coli. BMC Biotechnol. 2017, 17, 48. [CrossRef] [PubMed]

287. Zhou, X.; Hua, X.; Huang, L.; Xu, Y. Bio-utilization of cheese manufacturing wastes (cheese whey powder) for bioethanol and specific product (galactonic acid) production via a two-step bioprocess. Bioresour. Technol. 2019, 272, 70-76. [CrossRef] [PubMed]

288. Venkata Mohan, S.; Nikhil, G.N.; Chiranjeevi, P.; Nagendranatha Reddy, C.; Rohit, M.V.; Kumar, A.N.; Sarkar, O. Waste biorefinery models towards sustainable circular bioeconomy: Critical review and future perspectives. Bioresour. Technol. 2016, 215, 2-12. [CrossRef] [PubMed]

289. O'Callaghan, K. Technologies for the utilisation of biogenic waste in the bioeconomy. Food Chem. 2016, 198, 2-11. [CrossRef] [PubMed]

290. Bekatorou, A.; Plioni, I.; Sparou, K.; Maroutsiou, R.; Tsafrakidou, P.; Petsi, T.; Kordouli, E. Bacterial Cellulose Production Using the Corinthian Currant Finishing Side-Stream and Cheese Whey: Process Optimization and Textural Characterization. Foods 2019, 8, 193. [CrossRef] [PubMed]

291. Kopsahelis, N.; Dimou, C.; Papadaki, A.; Xenopoulos, E.; Kyraleou, M.; Kallithraka, S.; Kotseridis, Y.; Papanikolaou, S.; Koutinas, A.A. Refining of wine lees and cheese whey for the production of microbial oil, polyphenol-rich extracts and value-added co-products. J. Chem. Technol. Biotechnol. 2018, 93, 257-268. [CrossRef]

292. Dimitrellou, D.; Kandylis, P.; Kourkoutas, Y.; Kanellaki, M. Novel probiotic whey cheese with immobilized lactobacilli on casein. LWT 2017, 86, 627-634. [CrossRef]

293. Paximada, P.; Koutinas, A.A.; Scholten, E.; Mandala, I.G. Effect of bacterial cellulose addition on physical properties of WPI emulsions. Comparison with common thickeners. Food Hydrocoll. 2016, 54, $245-254$. [CrossRef]

294. Gama, A.P.; Hung, Y.-C.; Adhikari, K. Optimization of Emulsifier and Stabilizer Concentrations in a Model Peanut-Based Beverage System: A Mixture Design Approach. Foods 2019, 8, 116. [CrossRef]

295. Peng, J.; Calabrese, V.; Geurtz, J.; Velikov, K.P.; Venema, P.; van der Linden, E. Composite Gels Containing Whey Protein Fibrils and Bacterial Cellulose Microfibrils. J. Food Sci. 2019, 84, 1094-1103. [CrossRef] [PubMed]

296. Bavyko, O.; Bondarchuk, M. Ice-cream with functional properties as a means of commercial networks assortment extension and population feeding improving. J. Hyg. Eng. Des. 2019, 26, 127-133.

297. Agustini, T.W.; Ma'ruf, W.F.; Widayat, W.; Suzery, M.; Hadiyanto, H.; Benjakul, S. Application of Spirulina platensis on ice cream and soft cheese with respect to their nutritional and sensory perspectives. J. Teknol. 2016, 78, 245-251. [CrossRef]

298. Moreira, J.B.; Lim, L.-T.; da Zavareze, R.E.; Dias, A.R.G.; Costa, J.A.V.; de Morais, M.G. Antioxidant ultrafine fibers developed with microalga compounds using a free surface electrospinning. Food Hydrocoll. 2019, 93, 131-136. [CrossRef]

299. Batista, A.P.; Nunes, M.C.; Fradinho, P.; Gouveia, L.; Sousa, I.; Raymundo, A.; Franco, J.M. Novel foods with microalgal ingredients-Effect of gel setting conditions on the linear viscoelasticity of Spirulina and Haematococcus gels. J. Food Eng. 2012, 110, 182-189. [CrossRef] 
300. Gouveia, L. Spirulina maxima and Diacronema vlkianum microalgae in vegetable gelled desserts. Nutr. Food Sci. 2008, 38, 492-501. [CrossRef]

301. Terpou, A.; Papadaki, A.; Lappa, I.K.; Kachrimanidou, V.; Bosnea, L.A.; Kopsahelis, N. Probiotics in Food Systems: Significance and Emerging Strategies Towards Improved Viability and Delivery of Enhanced Beneficial Value. Nutrients 2019, 11, 1591. [CrossRef] 